\title{
METALLOCENE POLYETHYLENE WAX SYNTHESIS
}

Jessica V. Lamb, $\uparrow$ Jean-Charles Buffet, $\uparrow$ Zoë R. Turner, $\uparrow$ Tossapol Khamnaen, $\uparrow$ and Dermot $\mathrm{O}^{\prime}$ Hare $(*) \dagger$

$\dagger$ Chemistry Research Laboratory, Department of Chemistry, University of Oxford, 12 Mansfield Road, Oxford, OX1 3TA, United Kingdom

+ SCG Chemicals Co., Ltd, 1 Siam Cement Rd, Bangkok 10800, Thailand

Ethylene $/ \mathrm{H}_{2}$ polymerization, polyethylene wax, solid polymethylaluminoxane, high-throughput polymerization, permethylindenyl, zirconocenes

TOC
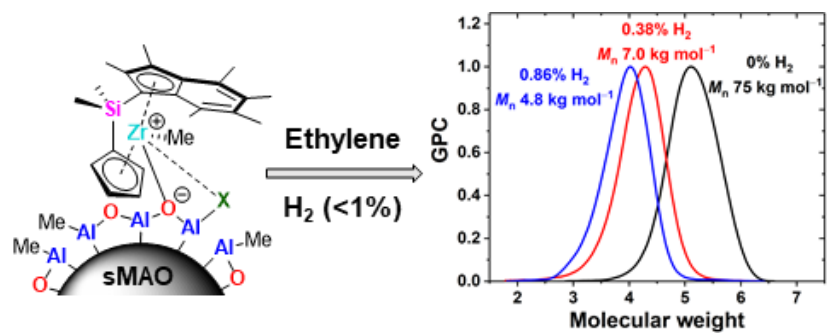

\section{ABSTRACT}

Solid polymethylaluminoxane (sMAO) supported ansa-bridged permethylindenyl zirconocenes ${ }^{\mathrm{Me}_{2}} \mathrm{SB}\left(\mathrm{Cp}^{\mathrm{R}}, \mathrm{I}^{*}\right) \mathrm{ZrX} \mathrm{X}_{2}\left(\left\{\left(\eta^{5}-\mathrm{C}_{9} \mathrm{Me}_{6}\right) \mathrm{Me}_{2} \mathrm{Si}\left(\eta^{5}-\mathrm{C}_{5} \mathrm{H}_{3} \mathrm{R}\right)\right\} \mathrm{ZrX} \mathrm{X}_{2} ; \mathrm{R}=\mathrm{H}, \mathrm{Me}\right.$, and ${ }^{n} \mathrm{Bu} ; \mathrm{X}=\mathrm{Cl}, \mathrm{Br}, \mathrm{Me}$, and $\left.\mathrm{CH}_{2} \mathrm{Ph}\right)$ have been investigated as catalysts for the slurry-phase polymerization of ethylene in the presence of $\mathrm{H}_{2}$. The catalysts demonstrated remarkable stability to $\mathrm{H}_{2}$ both in a high-throughput screening system and in a $2 \mathrm{~L}$ batch reactor, with an almost constant ethylene uptake maintained throughout the polymerization runs. The catalysts demonstrated very high ethylene polymerization activities, almost three times higher than sMAO- $\left(\mathrm{Cp}^{n \mathrm{Bu}}\right)_{2} \mathrm{ZrCl}_{2}$ (industrial standard zirconocene catalyst) under the same conditions. The presence of small quantities of $\mathrm{H}_{2}(<1 \%)$ led to significant decreases in polymer molecular weights to produce commercially desirable polyethylene waxes $\left(M_{\mathrm{n}}<10 \mathrm{~kg} \mathrm{~mol}^{-1}\right)$ in the batch reactor. 


\section{INTRODUCTION}

Polymer properties such as molecular weights $\left(M_{\mathrm{w}}\right.$ and $\left.M_{\mathrm{n}}\right)$, molecular weights distributions (MWD, $\left.M_{\mathrm{w}} / M_{\mathrm{n}}\right)$, the degree of branching, comonomer incorporation, and stereochemistry determine the potential applications of a polymer. ${ }^{1}$ Dihydrogen $\left(\mathrm{H}_{2}\right)$ is a highly efficient chain transfer agent for the polymerization of $\alpha$-olefins by metallocene catalysts and is often employed to both decrease and control polymer molecular weights. ${ }^{2,3}$ Contrary to conventional Ziegler-Natta catalysts, only a small quantity of $\mathrm{H}_{2}$ is required to significantly reduce polymer molecular weights. ${ }^{2,4,5}$

Group 4 metallocenes are $\mathrm{d}^{0}$ organometallic compounds containing two $\eta^{5}$-cyclopentadienyl $\left(\mathrm{C}_{5} \mathrm{H}_{5}\right.$, $\mathrm{Cp})$ ligands and two $\sigma$-type ligands $\left(\mathrm{Cp}_{2} \mathrm{MX}_{2}\right)$. In comparison to traditional Ziegler-Natta catalysts, ${ }^{6}$ metallocene catalysts provide a multitude of possibilities for synthesizing and controlling the structure and properties of polymers. ${ }^{7-9}$ In addition, the single-site nature of metallocene catalysts usually results in polymers with unimodal molecular weight distributions. ${ }^{10}$ Variation of the ancillary cyclopentadienyl ligands of $\mathrm{Cp}_{2} \mathrm{MX}_{2}$ species can influence polymerization activity and polymer properties. We recently reported a new family of unsymmetrical ansa-bridged zirconocenes based on the permethylindenyl ligand $\left(\mathrm{C}_{9} \mathrm{Me}_{7}{ }^{-}\right.$, Ind*, I*) as catalysts for ethylene and lactide polymerization (Chart 1). ${ }^{11-15}$ When immobilized on solid polymethylaluminoxane (sMAO), an insoluble form of oligomeric methylaluminoxane (MAO), the species showed slurry-phase ethylene polymerization activities up to $9509 \mathrm{~kg}_{\mathrm{PE}}$ mol $_{\mathrm{Zr}}^{-1} \mathrm{~h}^{-1} \mathrm{bar}^{-1} ; 34 \%$ more active than an industry-standard metallocene under the same conditions. ${ }^{11}$ These systems produced polyethylenes with low molecular weights $\left(M_{\mathrm{n}}=14 \mathrm{~kg} \mathrm{~mol}^{-1}\right.$ for sMAO supported ${ }^{\mathrm{Me}_{2}} \mathrm{SB}\left(\mathrm{Cp}, \mathrm{I}^{*}\right) \mathrm{ZrMe}_{2}$ at $\left.90{ }^{\circ} \mathrm{C}\right)$, and uniform, mono-disperse 'popcorn' morphologies. 


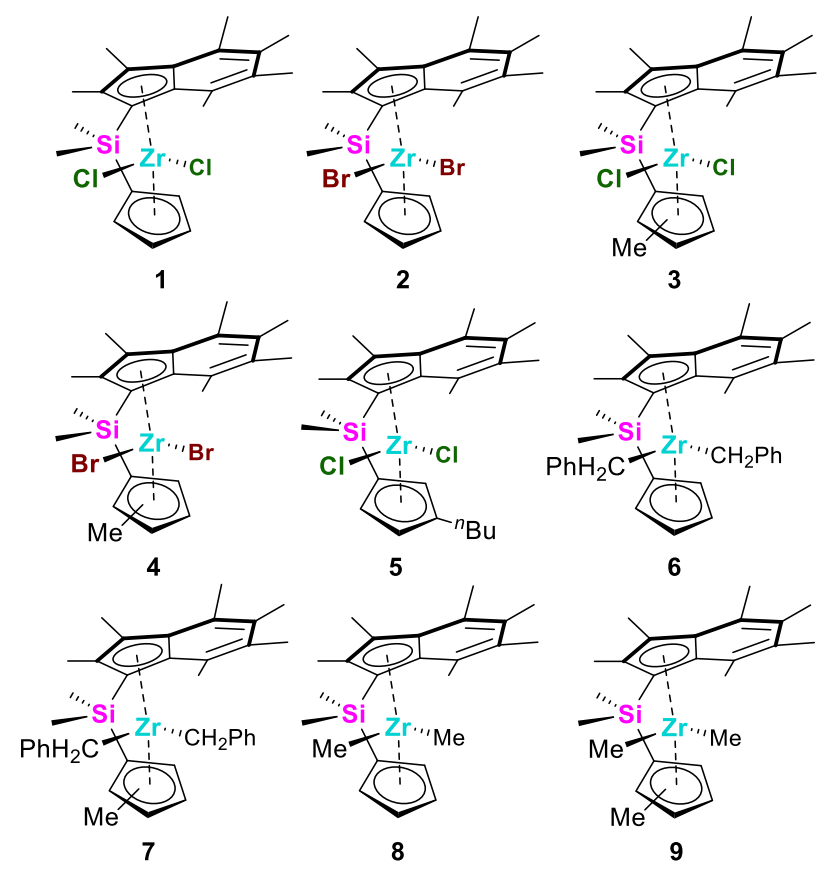

Chart 1. Group 4 permethylindenyl complexes ${ }^{\mathrm{Me}_{2}} \mathrm{SB}\left(\mathrm{Cp}, \mathrm{I}^{*}\right) \mathrm{ZrCl}_{2} \quad$ (1), ${ }^{12}{ }^{\mathrm{Me}_{2}} \mathrm{SB}\left(\mathrm{Cp}, \mathrm{I}^{*}\right) \mathrm{ZrBr}_{2} \quad$ (2), ${ }^{11}$ ${ }^{\mathrm{Me}_{2}} \mathrm{SB}\left(\mathrm{Cp}^{\mathrm{Me}}, \mathrm{I}^{*}\right) \mathrm{ZrCl}_{2} \quad$ (3), ${ }^{12} \quad{ }^{\mathrm{Me}_{2}} \mathrm{SB}\left(\mathrm{Cp}^{\mathrm{Me}}, \mathrm{I}^{*}\right) \mathrm{ZrBr}_{2} \quad$ (4), ${ }^{11} \quad Z_{-}{ }^{\mathrm{Me}_{2}} \mathrm{SB}\left(\mathrm{Cp}^{n \mathrm{Bu}}, \mathrm{I}^{*}\right) \mathrm{ZrCl}_{2} \quad$ (5), ${ }^{11}$ ${ }^{\mathrm{Me}_{2}} \mathrm{SB}\left(\mathrm{Cp}, \mathrm{I}^{*}\right) \mathrm{Zr}\left(\mathrm{CH}_{2} \mathrm{Ph}\right)_{2} \quad(\mathbf{6}),{ }^{11} \quad{ }^{\mathrm{Me}_{2}} \mathrm{SB}\left(\mathrm{Cp}^{\mathrm{Me}}, \mathrm{I}^{*}\right) \mathrm{Zr}\left(\mathrm{CH}_{2} \mathrm{Ph}\right)_{2} \quad(\mathbf{7}),{ }^{11} \quad{ }^{\mathrm{Me}_{2}} \mathrm{SB}\left(\mathrm{Cp}, \mathrm{I}^{*}\right) \mathrm{ZrMe}_{2} \quad(\mathbf{8}),{ }^{11} \quad$ and ${ }^{\mathrm{Me}_{2}} \mathrm{SB}\left(\mathrm{Cp}^{\mathrm{Me}}, \mathrm{I}^{*}\right) \mathrm{ZrMe}_{2}(\mathbf{9}) .{ }^{11}$

Polyethylene waxes (PE-waxes) are polymers with molecular weights $\left(M_{\mathrm{n}}\right)$ less than $10 \mathrm{~kg} \mathrm{~mol}^{-1} .{ }^{16}$,

${ }^{17}$ PE-waxes can be made directly from the polymerization of ethylene under controlled conditions or by the thermal degradation of higher molecular weight polymers. ${ }^{18,19}$ Due to their hydrophobicity and chemical and heat stability, ${ }^{20,21} \mathrm{PE}$-waxes are used in plastic processing applications to improve product physical appearance and thermal properties. PE-waxes are also commonly used as additives to impart mark, slip, rub, and scratch resistance in printing inks and paints, improve the fusing properties in toner formulations, improve the mechanical properties of surface coatings, and act as lubricating agents in plastic processing. ${ }^{18}$, ${ }^{19,22-24}$ PE-wax dispersions, obtained by the redispersion of low-density polyethylene (LDPE) in water, ${ }^{24-26}$ are targeted for use in coating applications in the paper industry. ${ }^{27}$ They are also used as surface modifiers for primers, paints, inks, coatings, and lubricants. ${ }^{24}$ Additionally, PE-wax emulsions, prepared by mixing 
modified high-density polyethylene (HDPE) with an emulsifier and water, have shown applications in packaging. $^{28}$

Limited examples of group 4 metallocenes have been reported as catalysts for the production of polyethylene waxes. ${ }^{17,29,30}$ However, there is a great incentive for their use as traditional Ziegler-Natta catalysts usually result in significant reactor fouling due to the broad molecular weight distributions of the waxes produced, which also contain substantial amounts of undesirable ethylene oligomers. ${ }^{30}$ Napoli et al. reported that when group 4 metallocenes such as bis(cyclopentadienyl)zirconium dichloride $\left(\mathrm{Cp}_{2} \mathrm{ZrCl}_{2}\right)$, rac-ethylenebis(1-indenyl)zirconium dichloride ( $r a c-(\mathrm{EBI}) \mathrm{ZrCl}_{2}$ ) and rac-dimethylsilyl-bis(2-methyl-4phenyl-1-indenyl)zirconium dichloride $\left(\mathrm{rac}_{-}{ }^{\mathrm{Me}_{2}} \mathrm{SB}\left({ }^{2-\mathrm{Me}, 4-\mathrm{Ph}} \mathrm{Ind}\right) \mathrm{ZrCl}_{2}\right)$ were activated by MAO, they polymerized ethylene in the solution phase in the presence of $\mathrm{H}_{2}$ and produced polyethylene waxes with molecular weights $\left(M_{\mathrm{n}}\right)$ less than $12 \mathrm{~kg} \mathrm{~mol}^{-1}$ and narrow molecular weight distributions $\left(M_{\mathrm{w}} / M_{\mathrm{n}}=2.0-3.5\right){ }^{17}$ In the patent literature, catalysts comprising of a group 4 metallocenes, such as bis(cyclopentadienyl)dimethyl zirconium $\left(\mathrm{Cp}_{2} \mathrm{ZrMe}_{2}\right)$ and $\mathrm{Cp}_{2} \mathrm{ZrCl}_{2}$, with an aluminoxane activator have been shown to produce polyethylene waxes with molecular weights $\left(M_{\mathrm{w}}\right)$ of $2-10 \mathrm{~kg} \mathrm{~mol}^{-1}$ and varying molecular weight distributions $\left(M_{\mathrm{w}} / M_{\mathrm{n}}=2-10\right)$ at relatively low temperatures $\left(70-90{ }^{\circ} \mathrm{C}\right)$ with $\mathrm{H}_{2}$ partial pressures of $1-10 \% .{ }^{29}$ Group 4 metallocenes such as bis( $n$-butylcyclopentadienyl)zirconium dichloride $\left(\left(\mathrm{Cp}^{n \mathrm{Bu}}\right)_{2} \mathrm{ZrCl}_{2}\right)$ activated with trimethylaluminum (TMA) and immobilized onto an aluminoxane coated silica gel have also been shown to produce polyethylene waxes with narrow molecular weight distributions $\left(M_{\mathrm{w}} / M_{\mathrm{n}} \leq 5\right)$ from the gas phase polymerization of ethylene in the presence of high amounts of $\mathrm{H}_{2}(7 \mathrm{~mol} \%) .{ }^{30}$

High-throughput screening is a useful tool for simultaneously testing catalysts under a variety of different conditions via robotic systems that automate sample preparation, handling, and data analysis. ${ }^{31,32}$ Miniaturized, automated, parallel reaction set-ups have been implemented for the rapid assessment of novel catalyst applications, while also being used for the generation of reliable kinetic data for mechanistic studies. ${ }^{33,34}$ High-throughput screening allows for reduced time in the design of new materials and faster optimization of reaction conditions. ${ }^{35}$ It also offers multiple technical, economic and environmental advantages over conventional processes; the small size of the reactors leads to decreased costs, chemical consumption 
and waste, in addition to the increased probability of discovering materials or conditions with the desired properties or results in a shorter time period. ${ }^{33}$ Busico and co-workers demonstrated that for a $\mathrm{MgCl}_{2} / \mathrm{TiCl}_{4}-\mathrm{AlEt}_{3}$ Ziegler-Natta catalyst, a high-throughput system gave the same ethylene/1-hexene copolymerization results as a $2 \mathrm{~L}$ batch reactor for catalyst activity, polymer molecular weights, and 1-hexene incorporation. ${ }^{33}$

High-throughput screening has also been shown to be a useful technique for the identification of new, selective organometallic catalysts for olefin polymerization. ${ }^{32,33,36,37}$ For example, the development of pyridyl-amide hafnium catalysts for the homopolymerization of 1-alkenes to produce highly isotactic polymers. ${ }^{36,38}$ The initial target was to identify novel catalysts for ethylene/1-octene copolymerization; however, high-throughput screening resulted in the identification of a catalyst with the ability to homopolymerize 1-alkenes isoselectively.

Herein, we report the synthesis of polyethylene waxes with narrow molecular weight distributions using highly active supported permethylindenyl zirconocene catalysts in a high-throughput screening system and large-scale batch reactor.

\section{RESULTS AND DISCUSSION}

High-throughput ethylene/ $\mathbf{H}_{2}$ polymerization The complexes in Chart 1 were immobilized on solid polymethylaluminoxane (sMAO) with an initial aluminum to zirconium catalyst loading ([A $\left.\left.1_{\mathrm{sMAO}}\right]_{0} /[\mathrm{Zr}]_{0}\right)$ of 200. ${ }^{11}$ Polymerizations were conducted in a high-throughput system, which allowed for multiple catalysts and conditions to be tested simultaneously in miniaturized, automated, parallel reaction set-ups. ${ }^{31,32}$ High-throughput polymerization studies were conducted in a parallel pressure reactor (PPR) in $23 \mathrm{~mL}$ cells with $5 \mathrm{~mL}$ heptane, $10 \mu \mathrm{mol}$ triisobutylaluminum (TiBA, $\left.\mathrm{Al}\left(\mathrm{CH}_{2} \mathrm{CH}\left(\mathrm{CH}_{3}\right)_{2}\right)_{3}\right)$ scavenger, $0.05-0.15 \mathrm{mg}$ pre-catalyst, 8.3 bar ethylene, and $0.8 \%$ (0.07 bar) or $1.6 \%\left(0.13\right.$ bar) $\mathrm{H}_{2}$ supplied by a mixed $\mathrm{H}_{2} / \mathrm{N}_{2}$ feed. Reactions were run at $80^{\circ} \mathrm{C}$ for 1 hour or until 8.3 bar ethylene uptake was reached. sMAO supported

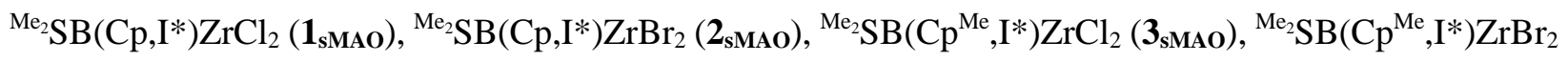




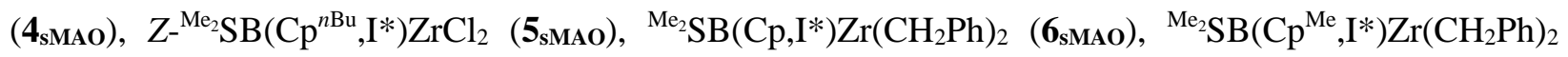
(7 sMAO $_{\text {) }},{ }^{\mathrm{Me}_{2}} \mathrm{SB}\left(\mathrm{Cp}, \mathrm{I}^{*}\right) \mathrm{ZrMe}_{2}\left(\mathbf{8}_{\text {sMAO }}\right)$, and ${ }^{\mathrm{Me}_{2}} \mathrm{SB}\left(\mathrm{Cp}^{\mathrm{Me}}, \mathrm{I}^{*}\right) \mathrm{ZrMe}_{2}\left(\boldsymbol{9}_{\text {sMAO }}\right)$ were studied.

For catalysts of this type, $\mathrm{H}_{2}$ is anticipated to cause a reduction in ethylene uptake rate over time. However, the ideal targets are systems that are not deactivated by $\mathrm{H}_{2}$ and maintain constant ethylene uptake rates throughout the polymerization runs. The in-situ ethylene uptake rate profiles of $\mathbf{1}_{\text {SMAOO}}-\mathbf{9}_{\text {SMAO }}$ highlight the stability of these catalysts in the presence of $\mathrm{H}_{2}$ (Figures 1 and $\mathrm{S} 1-\mathrm{S} 4$ ). When $\mathrm{H}_{2}$ was present, the ethylene uptake rates were lower than polymerization without $\mathrm{H}_{2}$; uptake rates of 11.77 , 4.82, and $3.58 \mathrm{psi} \mathrm{min}^{-1}$ for $\mathbf{8}_{\text {sMAO }}$ with $0,0.8$, and $1.6 \% \mathrm{H}_{2}$ respectively after 600 seconds (Figure 1). The uptake rates were also observed to slowly decrease over time (from $4.69 \mathrm{psi} \mathrm{min}^{-1}$ after 200 seconds to

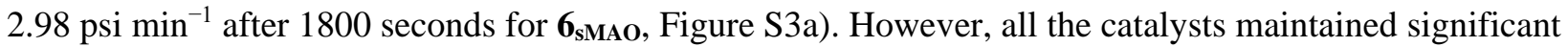
ethylene uptake rates on completion of the polymerization runs. $\mathbf{8}_{\text {sMAO }}$ showed the highest stability to $\mathrm{H}_{2}$, with a constant ethylene uptake rate of approximately $3.50 \mathrm{psi} \mathrm{min}^{-1}$ throughout the polymerization with $1.6 \% \mathrm{H}_{2}$ (Figure 1).

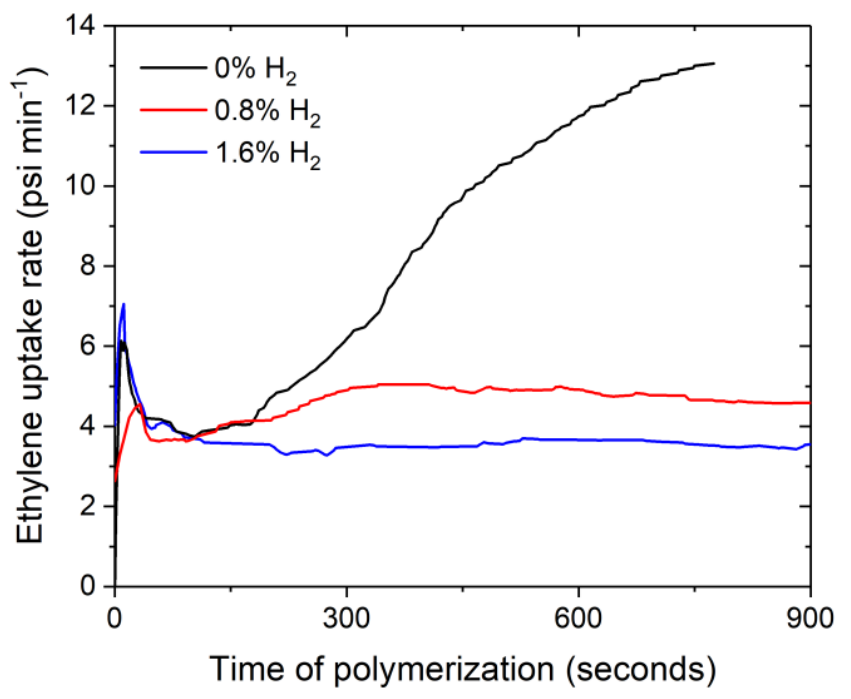

Figure 1. Slurry-phase polymerization ethylene uptake rate as a function of time of polymerization using sMAO supported ${ }^{\mathrm{Me}_{2}} \mathrm{SB}\left(\mathrm{Cp}, \mathrm{I}^{*}\right) \mathrm{ZrMe}_{2}\left(\mathbf{8}_{\text {sMAO }}\right)$ with 0 (black), 0.8 (red), and 1.6\% $\mathrm{H}_{2}$ (blue). Polymerization conditions: $\left[\mathrm{Al}_{\mathrm{sMAO}}\right]_{0} /[\mathrm{Zr}]_{0}=200$, TiBA $(10 \mu \mathrm{mol})$, ethylene $(8.3 \mathrm{bar})$, pre-catalyst $(0.05 \mathrm{mg})$, heptane (5 mL), and $80^{\circ} \mathrm{C}$. Reactions quenched at 8.3 bar ethylene uptake or after 1 hour. 
The catalysts showed a significant decrease in ethylene polymerization activity when $\mathrm{H}_{2}$ was introduced to the system (Figures 2 and S7; Table 1); however, they remained very active with activities of 44000, 18000, and $16000 \mathrm{~kg}_{\mathrm{PE}}$ molzr $^{-1} \mathrm{~h}^{-1} \mathrm{bar}^{-1}$ for $\mathbf{1}_{\mathrm{sMAO}}$ with $0,0.8$, and $1.6 \% \mathrm{H}_{2}$ respectively. The presence of $\mathrm{H}_{2}$ offers an alternative termination pathway to those typically observed for ethylene polymerization (such as transfer to another ethylene monomer, $\beta$-hydride elimination, and chain transfer to the aluminum co-catalyst $)^{39-41}$ whereby $\mathrm{H}_{2}$ binds to the free coordination site of the catalyst, leading to the release of the polymer chain and formation of a metal hydride species. ${ }^{40}$ The reduction in polymerization rate in the presence of $\mathrm{H}_{2}$ can be rationalized due to an increase in the formation of the metal hydride termination product, which requires reactivation for propagation by insertion of a monomer unit. ${ }^{40,42}$ It has been found that the rate of insertion of ethylene into the $\mathrm{Zr}-\mathrm{H}$ bond of the metal hydride is significantly slower than the rate of insertion into the $\mathrm{Zr}-\mathrm{Me}$ bond of the catalyst, leading to a reduction in polymerization rate. ${ }^{43-46}$ This has been modeled for the polymerization of 1-hexene using $(\mathrm{EBI}) \mathrm{ZrMe}_{2} / \mathrm{B}\left(\mathrm{C}_{6} \mathrm{~F}_{5}\right)_{3}$, where the rate of reinitiation of $\mathrm{Zr}-\mathrm{H}$ was found to be more than 1 order of magnitude slower than the rate of propagation of $\mathrm{Zr}-\mathrm{Me}{ }^{47}$ Solution phase ethylene/ $\mathrm{H}_{2}$ polymerization data using $\left.r a c-{ }^{\mathrm{Me}_{2}} \mathrm{SB}^{(2-\mathrm{Me}, 4-\mathrm{Ph}} \mathrm{Ind}\right) \mathrm{ZrCl}_{2}$ activated with MAO have shown that the activity increased from 770 to $1185 \mathrm{~kg}_{\mathrm{PE}}$ mol $_{\mathrm{Zr}}^{-1} \mathrm{~h}^{-1} \mathrm{bar}^{-1}$ for ethylene/ $\mathrm{H}_{2}$ polymerization (4.5 bar ethylene, 1.5 bar $\mathrm{H}_{2}$, and $80{ }^{\circ} \mathrm{C}$ ). ${ }^{17}$ However, the deactivating effect of $\mathrm{H}_{2}$ has been demonstrated for homogeneous ethylene polymerization using $\mathrm{Cp}_{2} \mathrm{ZrCl}_{2} / \mathrm{MAO}$, where activity decreased from 45000 to $21400 \mathrm{~kg}_{\mathrm{PE}}$ mol $_{\mathrm{Zr}}^{-1} \mathrm{~h}^{-1} \mathrm{bar}^{-1}$ with 0 and $0.5 \mathrm{~mol} \% \mathrm{H}_{2}$ respectively $\left(8\right.$ bar ethylene and $\left.70{ }^{\circ} \mathrm{C}\right) .^{5}$ After an initial increase in activity, $\mathrm{Cp}_{2} \mathrm{ZrCl}_{2}$ supported on $\mathrm{MAO}$ activated silica was also shown to experience a decrease in slurry-phase ethylene polymerization activity with increasing amounts of $\mathrm{H}_{2}$; activities of 430 and $400 \mathrm{~kg}_{\mathrm{PE}}$ mol $_{\mathrm{Zr}}^{-1} \mathrm{~h}^{-1}$ bar $^{-1}$ with 0 and 4.1 bar $\mathrm{H}_{2}$ respectively $\left(5.5\right.$ bar ethylene and $\left.60{ }^{\circ} \mathrm{C}\right) .{ }^{50}$ 


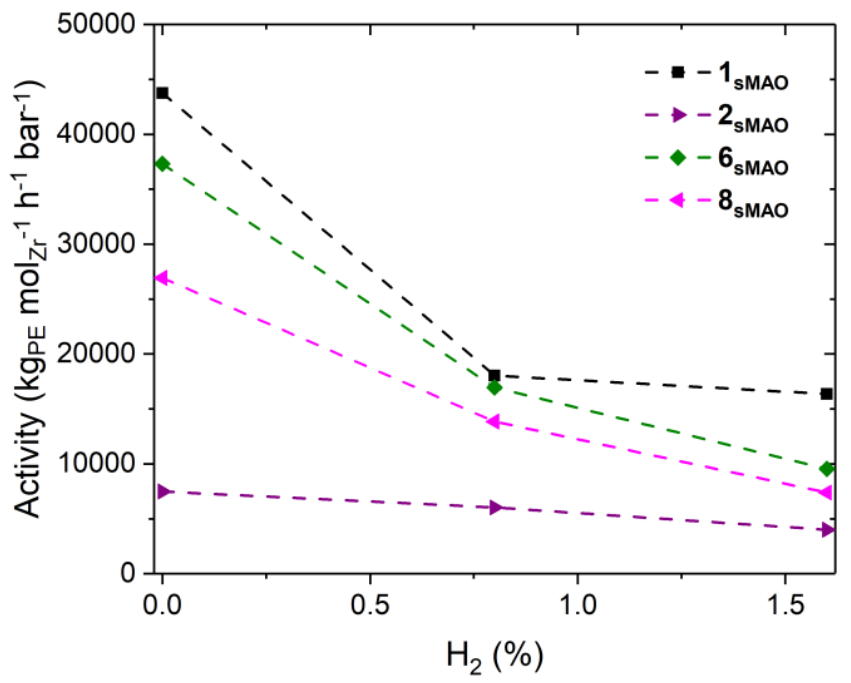

Figure 2. Slurry-phase ethylene polymerization activity as a function of $\mathrm{H}_{2}(\%)$ using sMAO supported ${ }^{\mathrm{Me}_{2}} \mathrm{SB}\left(\mathrm{Cp}, \mathrm{I}^{*}\right) \mathrm{ZrCl}_{2} \quad\left(\mathbf{1}_{\mathrm{sMAO}}\right) \quad\left(\right.$ black $\quad$ square), ${ }^{\mathrm{Me}_{2}} \mathrm{SB}\left(\mathrm{Cp}, \mathrm{I}^{*}\right) \mathrm{ZrBr}_{2} \quad\left(\mathbf{2}_{\mathrm{sMAO}}\right)$ (purple right triangle), ${ }^{\mathrm{Me}_{2}} \mathrm{SB}\left(\mathrm{Cp}, \mathrm{I}^{*}\right) \mathrm{Zr}\left(\mathrm{CH}_{2} \mathrm{Ph}\right)_{2}$ (6 $\left.\mathbf{6}_{\text {sMAo }}\right)$ (green diamond), and ${ }^{\mathrm{Me}_{2}} \mathrm{SB}\left(\mathrm{Cp}, \mathrm{I}^{*}\right) \mathrm{ZrMe}_{2}$ ( $\mathbf{8}_{\text {sMAo }}$ ) (pink left triangle). Polymerization conditions: $\left[\mathrm{Al}_{\mathrm{sMAO}}\right]_{0} /[\mathrm{Zr}]_{0}=200$, TiBA $(10 \mu \mathrm{mol})$, ethylene $(8.3 \mathrm{bar})$, pre-catalyst $(0.05-$ $0.15 \mathrm{mg})$, heptane $(5 \mathrm{~mL})$, and $80{ }^{\circ} \mathrm{C}$. Reactions quenched at 8.3 bar ethylene uptake or after 1 hour.

For sMAO- ${ }^{\mathrm{Me}_{2}} \mathrm{SB}\left(\mathrm{Cp}^{\mathrm{R}}, \mathrm{I}^{*}\right) \mathrm{ZrCl}_{2}$ catalysts, activity follows the same trend observed in previous work for ethylene homopolymerization using 2 bar ethylene and $50 \mathrm{~mL}$ solvent,${ }^{11} \mathrm{R}=\mathrm{H}>\mathrm{Me}>{ }^{n} \mathrm{Bu}\left(\mathbf{1}_{\text {sMAO }}>\right.$ $\mathbf{3}_{\text {sMAO }}>\mathbf{5}_{\text {sMAO }}$ ) (Table 1 and Figure S7b). This is rationalized due to larger R substituents obstructing the metal center and inhibiting the initial coordination of ethylene monomers. For sMAO- ${ }^{\mathrm{Me}_{2}} \mathrm{SB}\left(\mathrm{Cp}, \mathrm{I}^{*}\right) \mathrm{ZrX} \mathrm{X}_{2}$ catalysts, activity follows the order $\mathrm{X}=\mathrm{Cl}>\mathrm{CH}_{2} \mathrm{Ph}>\mathrm{Me}>\mathrm{Br}\left(\mathbf{1}_{\text {SMAO }}>\mathbf{6}_{\text {SMAO }}>\mathbf{8}_{\text {SMAO }}>\boldsymbol{2}_{\text {SMAO }}\right)$, which was also observed in previous work (Figure 2 and Table 1 ). ${ }^{11}$ As the same cationic species is usually formed regardless of the identity of the initiation group, ${ }^{7,51,52}$ the differences in activity suggests that polymerization activity is at least partially dependent on the efficiency of initiation group abstraction by the co-catalyst and by the presence of the initiating group on the surface of the inorganic support. For sMAO- ${ }^{\mathrm{Me}_{2}} \mathrm{SB}\left(\mathrm{Cp}^{\mathrm{Me}}, \mathrm{I}^{*}\right) \mathrm{ZrX} \mathrm{X}_{2}$ catalysts, $\mathrm{X}=\mathrm{Cl}\left(\mathbf{3}_{\mathrm{SMAO}}\right)$ displays a much higher polymerization activity than $\mathrm{X}=\mathrm{Me}, \mathrm{CH}_{2} \mathrm{Ph}$ or $\mathrm{Br}$ in the presence of $\mathrm{H}_{2}$, which is in contrast to $\mathrm{SMAO}-{ }^{\mathrm{Me}_{2}} \mathrm{SB}\left(\mathrm{Cp}, \mathrm{I}^{*}\right) \mathrm{ZrX}_{2}$ and previous 
studies and may be due to differences in the rate of formation of the metal hydride species (Table 1 and Figure S7a).

In general, gel permeation chromatography (GPC) showed the polymers produced in the presence of $1.6 \% \mathrm{H}_{2}$ had molecular weights $\left(M_{\mathrm{n}}\right)$ approximately 20 times smaller than in the systems without $\mathrm{H}_{2}$; for example, $M_{\mathrm{n}}=120$ and $6.1 \mathrm{~kg} \mathrm{~mol}^{-1}$ for $\mathbf{8}_{\text {sMAO }}$ with 0 and $1.6 \% \mathrm{H}_{2}$ respectively (Figures 3 and S9-13; Table 1). $M_{\mathrm{n}}$ was also observed to decrease as more $\mathrm{H}_{2}$ was added to the system; for example, $M_{\mathrm{n}}=120$, 14 , and $6.9 \mathrm{~kg} \mathrm{~mol}^{-1}$ for $\mathbf{6}_{\text {sMAO }}$ with $0,0.8$, and $1.6 \% \mathrm{H}_{2}$ respectively.

Table 1. Slurry-phase ethylene/ $\mathrm{H}_{2}$ polymerization using sMAO supported complexes in a high-throughput system. $^{\text {a }}$

\begin{tabular}{|c|c|c|c|c|}
\hline Catalyst & $\mathbf{H}_{2}{ }^{b}$ & Activity $^{c}$ & $M_{\mathrm{n}}{ }^{\mathrm{d}}$ & $M_{\mathrm{w}} / M_{\mathrm{n}}$ \\
\hline \multirow{3}{*}{$1_{\text {SMAO }}$} & 0 & 44000 & 110 & 3.2 \\
\hline & 0.8 & 18000 & 14 & 2.3 \\
\hline & 1.6 & 16000 & 11 & 2.0 \\
\hline \multirow{3}{*}{$2_{\text {SMAO }}$} & 0 & 7500 & 120 & 2.4 \\
\hline & 0.8 & 6000 & 11 & 2.6 \\
\hline & 1.6 & 4000 & 7.1 & 2.6 \\
\hline \multirow{3}{*}{$3_{\text {SMAO }}$} & 0 & 20000 & 110 & 3.0 \\
\hline & 0.8 & 16000 & 11 & 2.9 \\
\hline & 1.6 & 12000 & 5.1 & 2.9 \\
\hline \multirow{3}{*}{$\mathbf{4}_{\text {SMAO }}$} & 0 & 6600 & 120 & 2.9 \\
\hline & 0.8 & 3500 & 8.9 & 3.4 \\
\hline & 1.6 & 1900 & 4.5 & 3.6 \\
\hline \multirow{3}{*}{$5_{\text {SMAO }}$} & 0 & 38000 & 63 & 2.4 \\
\hline & 0.8 & 4000 & 6.7 & 3.6 \\
\hline & 1.6 & 3800 & 4.3 & 3.4 \\
\hline \multirow{2}{*}{$6_{\text {SMAO }}$} & 0 & 37000 & 120 & 2.5 \\
\hline & 0.8 & 17000 & 14 & 2.5 \\
\hline
\end{tabular}




\begin{tabular}{|c|c|c|c|c|}
\hline & 1.6 & 9500 & 6.9 & 2.4 \\
\hline \multirow{3}{*}{$7_{\text {sMAO }}$} & 0 & 23000 & 110 & 3.3 \\
\cline { 2 - 5 } & 0.8 & 5000 & 7.5 & 3.7 \\
\cline { 2 - 5 } & 1.6 & 4000 & 3.9 & 3.9 \\
\hline \multirow{3}{*}{$8_{\text {sMAO }}$} & 0 & 27000 & 120 & 3.0 \\
\cline { 2 - 5 } & 0.8 & 14000 & 11 & 2.6 \\
\cline { 2 - 5 } & 1.6 & 7400 & 6.1 & 2.7 \\
\hline \multirow{3}{*}{ 9 $_{\text {sMAO }}$} & 0 & 17000 & 110 & 3.1 \\
\cline { 2 - 5 } & 0.8 & 3400 & 6.9 & 3.6 \\
\cline { 2 - 5 } & 1.6 & 2660 & 3.9 & 3.8 \\
\hline
\end{tabular}

(a) Polymerization conditions: $\left[\mathrm{Al}_{\mathrm{sMAO}}\right]_{0} /[\mathrm{Zr}]_{0}=200$, TiBA $(10 \mu \mathrm{mol})$, ethylene $(8.3$ bar $)$, pre-catalyst (0.05-0.15 mg), heptane $(5 \mathrm{~mL})$, and $80{ }^{\circ} \mathrm{C}$. Reactions quenched at 8.5 bar ethylene uptake or after 1 hour; (b) $\%$; (c) $\mathrm{kg}_{\mathrm{PE}}$ molzr $^{-1} \mathrm{~h}^{-1} \mathrm{bar}^{-1}$, reported to 2 significant figures; (d) $\mathrm{kg} \mathrm{mol}^{-1}$, reported to 2 significant figures.

The polymers produced in the presence of $\mathrm{H}_{2}$ are classed as ultra-low molecular weight polyethylenes, PE-wax, with $M_{\mathrm{n}}$ of 4-11 $\mathrm{kg} \mathrm{mol}^{-1}$. The decrease in molecular weights in the presence of $\mathrm{H}_{2}$ is most likely due to the increased amount of chain termination that occurs when $\mathrm{H}_{2}$ acts as a chain transfer agent. A decrease in polymer molecular weights in the presence of $\mathrm{H}_{2}$ has also been observed by Soares and coworkers when using rac-(EBI) $\mathrm{ZrCl}_{2}$ supported on $\mathrm{MAO}$ treated silica; $M_{\mathrm{w}}$ decreased from approximately 100 to $3 \mathrm{~kg} \mathrm{~mol}^{-1}$ in the presence of 2 bar $\mathrm{H}_{2}\left(60{ }^{\circ} \mathrm{C}\right.$ and 5.5 bar ethylene $) .{ }^{50}$ 


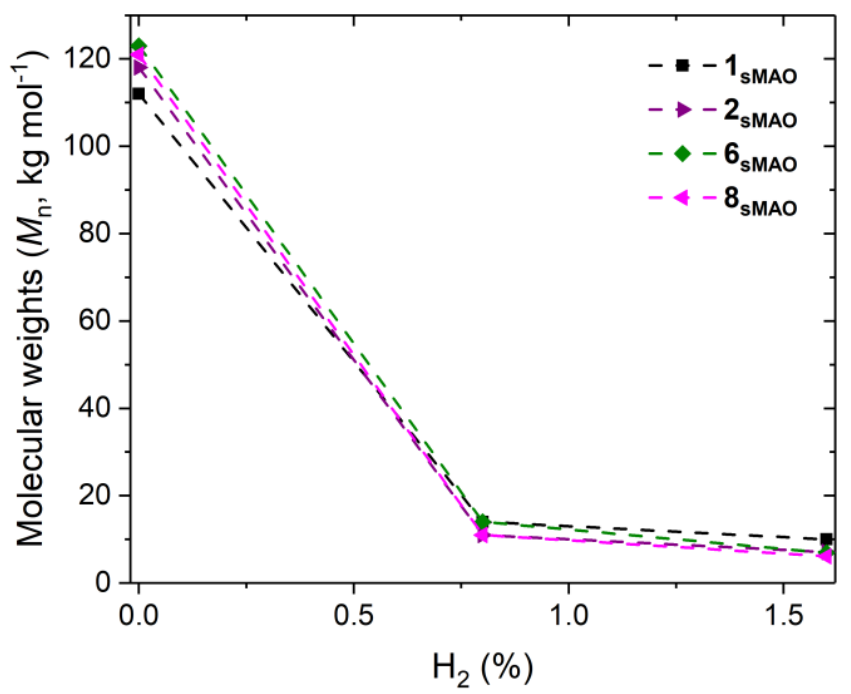

Figure 3. Polymer molecular weights $\left(M_{\mathrm{n}}\right)$ as a function of $\mathrm{H}_{2}(\%)$ for the polymers produced using sMAO

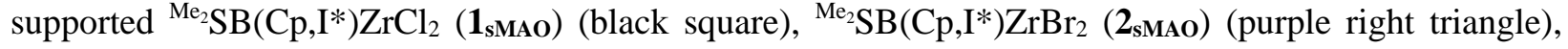
${ }^{\mathrm{Me}_{2}} \mathrm{SB}\left(\mathrm{Cp}, \mathrm{I}^{*}\right) \mathrm{Zr}\left(\mathrm{CH}_{2} \mathrm{Ph}\right)_{2}\left(\boldsymbol{6}_{\text {sMAO }}\right)$ (green diamond), and ${ }^{\mathrm{Me}_{2}} \mathrm{SB}\left(\mathrm{Cp}, \mathrm{I}^{*}\right) \mathrm{ZrMe}_{2}\left(\mathbf{8}_{\text {sMAo }}\right.$ ) (pink left triangle). Polymerization conditions: $\left[\mathrm{Al}_{\mathrm{sMAO}}\right]_{0} /[\mathrm{Zr}]_{0}=200$, TiBA $(10 \mu \mathrm{mol})$, ethylene $(8.3$ bar $)$, pre-catalyst $(0.05-$ $0.15 \mathrm{mg})$, heptane $(5 \mathrm{~mL})$, and $80^{\circ} \mathrm{C}$. Reactions quenched at 8.3 bar ethylene uptake or after 1 hour.

The activation barrier for $\mathrm{H}_{2}$ insertion has been calculated to be lower than that for ethylene insertion, indicating why only a small amount of $\mathrm{H}_{2}$ is required to reduce polymer molecular weights drastically. ${ }^{53}$ The molecular weight distributions $\left(M_{\mathrm{w}} / M_{\mathrm{n}}\right)$ were found to be fairly narrow and unaffected by the presence of $\mathrm{H}_{2}$, ranging between 2.0 to 3.9 for all solid MAO supported catalysts, indicating that these species behave largely as single-site catalysts (Table 1).

Crystallization-elution fractionation $(\mathrm{CEF})$ was used to measure the elution temperature $\left(T_{\mathrm{el}, \mathrm{max}}\right)$ of the polymers, which decreases as the melting point and crystallinity of the polymer decreases. $T_{\mathrm{el}, \max }$ was found to decrease slightly in the presence of $\mathrm{H}_{2}\left(T_{\mathrm{el}, \max }\right.$ of $110.9,109.9$, and $109.3{ }^{\circ} \mathrm{C}$ with $0,0.8$, and $1.6 \%$

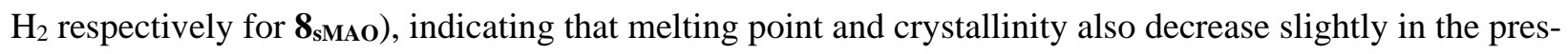
ence of $\mathrm{H}_{2}$ (Table S1; Figures S18 and S19). The amorphous fraction (AF) increased as the $\mathrm{H}_{2}$ concentration increased; $\mathrm{AF} \leq 0.4, \leq 2.2$, and $\leq 3.5 \mathrm{wt} \%$ for all catalysts with $0,0.8$, and $1.6 \% \mathrm{H}_{2}$ respectively. 


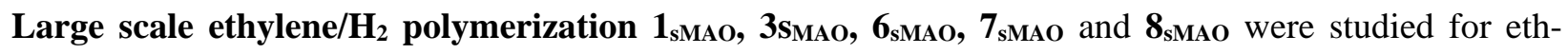
ylene/ $\mathrm{H}_{2}$ polymerization in $2 \mathrm{~L}$ steel batch reactors. Polymerizations were run at $80{ }^{\circ} \mathrm{C}$ for 1 hour with $1 \mathrm{~L}$ hexane, $2.5 \mathrm{~mL}$ triethylaluminum (TEA, $\left.\mathrm{Al}_{2}\left(\mathrm{C}_{2} \mathrm{H}_{5}\right)_{6}\right)$ scavenger, $0.025-0.070 \mathrm{~g}$ pre-catalyst, $\left[\mathrm{Al} 1_{\mathrm{sMAO}}\right]_{0} /[\mathrm{Zr}]_{0}$ of 200,8 bar ethylene gas, and either $0,0.38$ ( 0.03 bar) or $0.86 \%\left(0.07\right.$ bar) $\mathrm{H}_{2}$.

Similar to the high-throughput system, the presence of $\mathrm{H}_{2}$ decreased the ethylene uptake rate compared to polymerization without $\mathrm{H}_{2}$; uptake rates of 17.81 and $5.28 \mathrm{~L} \mathrm{mg}_{\mathrm{CAT}}{ }^{-1} \min ^{-1}$ for $\mathbf{8}_{\text {SMAO }}$ after 60 minutes with 0 and $0.86 \% \mathrm{H}_{2}$ respectively (Figures 4, S5, and S6).

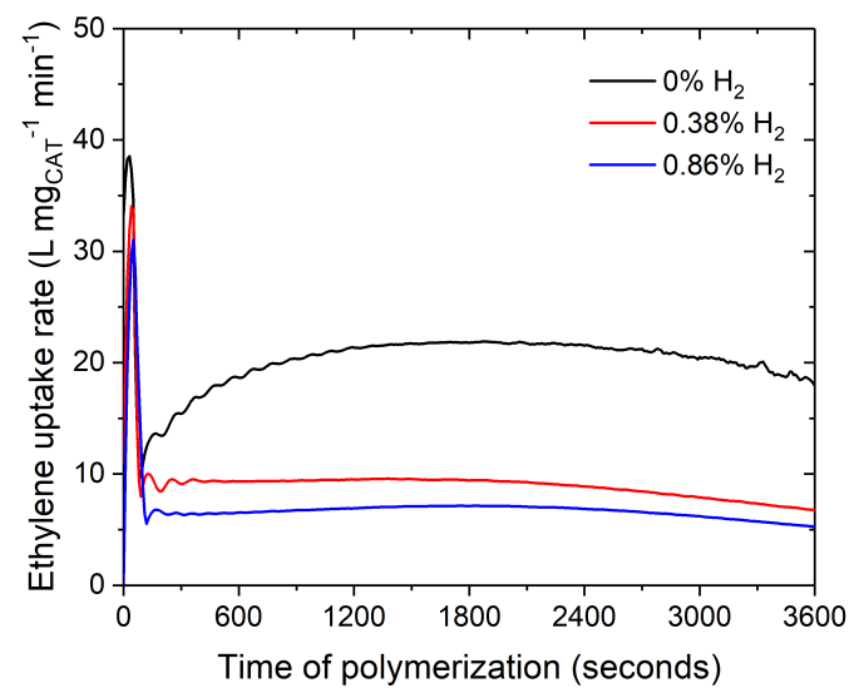

Figure 4. Slurry-phase polymerization ethylene uptake rate as a function of time of polymerization using sMAO supported ${ }^{\mathrm{Me}_{2}} \mathrm{SB}\left(\mathrm{Cp}, \mathrm{I}^{*}\right) \mathrm{ZrMe}_{2}\left(\mathbf{8}_{\text {sMAo }}\right)$ with 0 (black), 0.38 (red), and $0.86 \% \mathrm{H}_{2}$ (blue). Polymerization conditions: $\left[\mathrm{Al}_{\mathrm{sMAO}}\right]_{0} /[\mathrm{Zr}]_{0}=200$, TEA $(0.5 \mathrm{mmol})$, ethylene $(8 \mathrm{bar})$, pre-catalyst $(0.025-0.050 \mathrm{~g})$, hexane $(1 \mathrm{~L}), 80^{\circ} \mathrm{C}$, and 1 hour.

For most catalysts, the uptake rate was also shown to decrease gradually over time; for example, 5.76 and $3.08 \mathrm{~L} \mathrm{mg}_{\mathrm{CAT}}{ }^{-1} \mathrm{~min}^{-1}$ for $\mathbf{6}_{\text {sMAO }}$ after 600 and 3600 seconds respectively with $0.86 \% \mathrm{H}_{2}$. However, $\mathbf{1}_{\text {sMAO }}$ and $\mathbf{8}_{\text {sMaO }}$ displayed the highest stability to $\mathrm{H}_{2}$, with uptake rates of 6.54 and $5.28 \mathrm{~L} \mathrm{mg}_{\mathrm{CAT}}{ }^{-1} \mathrm{~min}^{-1}$ for $\mathbf{8}_{\text {SMAO }}$ after 600 and 3600 seconds respectively with $0.86 \% \mathrm{H}_{2}$.

As observed in the high-throughput system, activity decreased as the amount of $\mathrm{H}_{2}$ in the reactor was increased. However, all catalysts maintain very high activities (Table 2 and Figure S8). For $\mathbf{1}_{\text {sMAo }}$ and 


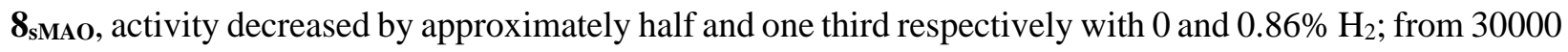
to $13000 \mathrm{~kg}_{\mathrm{PE}}$ mol $_{\mathrm{Zr}}^{-1} \mathrm{~h}^{-1}$ bar $^{-1}$ and from 27000 to $8900 \mathrm{~kg}_{\mathrm{PE}}$ mol $_{\mathrm{Zr}}^{-1} \mathrm{~h}^{-1}$ bar $^{-1}$ respectively. In addition to the formation of the metal hydride species, the reduction in activity on the introduction of $\mathrm{H}_{2}$ to the system may be due to the decreased solubility of ethylene monomers in the hexane solvent in the presence of $\mathrm{H}_{2}{ }^{54}$ For $\mathbf{1}_{\text {sMAO }}$, additional experiments were run using higher concentrations of $\mathrm{H}_{2}(2.00$ and $3.50 \%)$. When $\mathrm{H}_{2}$ was increased from $0.86 \%$ to $3.50 \%$, activity decreased by approximately a third to $4200 \mathrm{~kg}_{\mathrm{PE}} \operatorname{mol}_{\mathrm{Zr}}^{-1} \mathrm{~h}^{-1} \mathrm{bar}^{-1}$. When compared to an industrial standard, sMAO supported $\left(\mathrm{Cp}^{n \mathrm{Bu}}\right)_{2} \mathrm{ZrCl}_{2}$, $\mathbf{1}_{\text {sMAO }}$ afforded productivities almost three times higher under the same polymerization conditions; productivities of 1.2 and $3.2 \mathrm{~kg}_{\mathrm{PE}} \mathrm{g}_{\mathrm{CAT}}^{-1}$ respectively with $3.50 \% \mathrm{H}_{2}$.

Polymer molecular weights $\left(M_{\mathrm{n}}\right)$ significantly decreased with increasing $\mathrm{H}_{2}$ concentration; from 75 to $4.8 \mathrm{~kg} \mathrm{~mol}^{-1}$ for $\mathbf{8}_{\text {sMaO }}$ with 0 and $0.86 \% \mathrm{H}_{2}$ respectively (Table 2 and Figures $\mathrm{S} 14-\mathrm{S} 17$ ). For $\mathbf{1}_{\text {sMaO }}$, the molecular weights of the isolated polymers continued to decrease as the amount of $\mathrm{H}_{2}$ in the system was increased further. The lowest recorded polymer molecular weights were isolated using $\mathbf{1}_{\text {SMAO }}$ in the presence of 2.00 and $3.50 \% \mathrm{H}_{2}$, with $M_{\mathrm{n}}$ reaching as low as $1.7 \mathrm{~kg} \mathrm{~mol}^{-1}$. This demonstrates the applications of these catalysts for the production of commercially viable polyethylene waxes. In general, the molecular weight distributions of the polymers were unaffected by the presence of $\mathrm{H}_{2}$ (Table 2). However, $M_{\mathrm{w}} / M_{\mathrm{n}}$ was observed to increase when moving from the high-throughput system to the batch reactor, especially for $\mathbf{1}_{\text {sMao; }}$; $M_{\mathrm{w}} / M_{\mathrm{n}}$ of 3.2 and 5.0 with $0 \% \mathrm{H}_{2}$ in the high-throughput and batch reactor respectively. This may be due to the different conditions of polymerization between the two systems (e.g. TiBA vs. TEA activator, heptane vs. hexane solvent or variations in how the ethylene and $\mathrm{H}_{2}$ are supplied to the reactor) and indicates that polymerization is less controlled on a larger scale.

Table 2. Slurry-phase ethylene/ $\mathrm{H}_{2}$ polymerization using sMAO supported complexes in a $2 \mathrm{~L}$ batch reactor. $^{a}$

\begin{tabular}{|l|l|l|l|l|}
\hline Catalyst & $\mathbf{H}_{2}{ }^{\mathrm{b}}$ & Activity $^{\mathrm{c}}$ & $M_{\mathrm{n}}{ }^{\mathrm{d}}$ & $M_{\mathrm{w}} / M_{\mathrm{n}}$ \\
\hline
\end{tabular}




\begin{tabular}{|c|c|c|c|c|}
\hline \multirow{4}{*}{$\mathbf{1}_{\text {SMAO }}$} & 0 & 30000 & 53 & 5.0 \\
\hline & 0.86 & 13000 & - & - \\
\hline & 2.00 & 6400 & 2.1 & 5.8 \\
\hline & 3.50 & 4200 & 1.7 & 6.5 \\
\hline \multirow{3}{*}{$3_{\text {SMAO }}$} & 0 & 12000 & 69 & 3.6 \\
\hline & 0.38 & 7400 & 9.7 & 3.5 \\
\hline & 0.86 & 7600 & 5.0 & 3.8 \\
\hline \multirow{3}{*}{$6_{\text {SMAO }}$} & 0 & 12000 & 71 & 3.8 \\
\hline & 0.38 & 6900 & 9.2 & 3.0 \\
\hline & 0.86 & 6700 & 5.2 & 2.7 \\
\hline \multirow{3}{*}{$7_{\text {sMAO }}$} & 0 & 22000 & 69 & 3.0 \\
\hline & 0.38 & 9500 & 6.8 & 4.1 \\
\hline & 0.86 & 7200 & 4.6 & 4.1 \\
\hline \multirow{3}{*}{$8_{\text {sMAO }}$} & 0 & 27000 & 75 & 3.0 \\
\hline & 0.38 & 12000 & 7.0 & 3.8 \\
\hline & 0.86 & 8900 & 4.8 & 3.2 \\
\hline
\end{tabular}

(a) Polymerization conditions: $\left[\mathrm{Al}_{\mathrm{SMAO}}\right]_{0} /[\mathrm{Zr}]_{0}=200$, TEA $(2.5 \mathrm{~mL})$, ethylene $(8 \mathrm{bar})$, pre-catalyst $(0.025-$ $0.070 \mathrm{~g}$ ), hexane $(1 \mathrm{~L}), 80{ }^{\circ} \mathrm{C}$, and 1 hour; (b) \%; (c) $\mathrm{kg}_{\mathrm{PE}}$ molzr $^{-1} \mathrm{~h}^{-1} \mathrm{bar}^{-1}$, reported to 2 significant figures; (d) $\mathrm{kg} \mathrm{mol}^{-1}$.

Scanning electron microscopy (SEM) shows that the polyethylenes formed in the absence of $\mathrm{H}_{2}$ have very uniform, 'popcorn' morphologies (Figure S20). ${ }^{11}$ The presence of $\mathrm{H}_{2}$ was found to have little effect on the morphologies of the polymers, with the same 'popcorn' morphology observed using $\mathbf{1}_{\text {sMao }}$ with 0, 2.00, and 3.50\% $\mathrm{H}_{2}$ (Figures 5, S20, and $\mathrm{S} 21$ ).

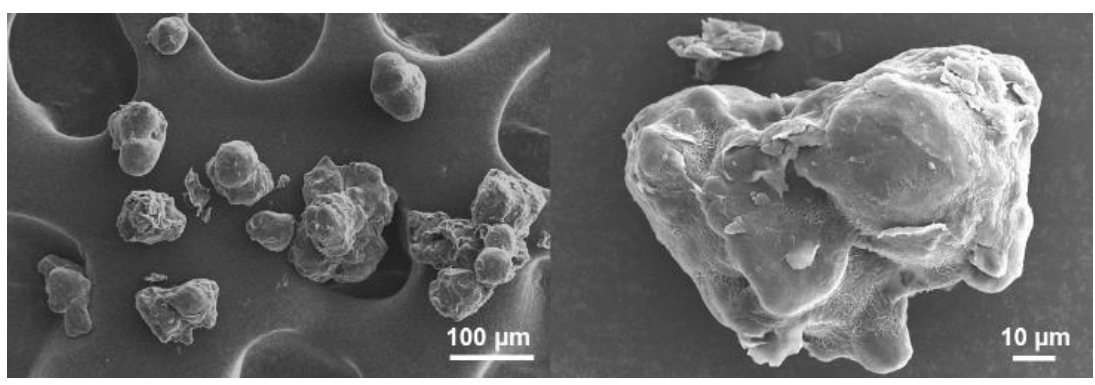


Figure 5. SEM images at $\times 200$ and $\times 1000$ magnification of the polymers produced from the slurry-phase polymerization of ethylene using $\mathbf{1}_{\text {sMAO }}$ in the presence of $2.00 \% \mathrm{H}_{2}$.

The polymers produced using $\mathbf{7}_{\text {sMAO }}$ and $\mathbf{8}_{\text {sMAO }}$ were found by differential scanning calorimetry (DSC) to have a high crystallinity ( 83 and $86 \%$ respectively in the presence of $0.86 \% \mathrm{H}_{2}$ ) and melting temperature $\left(T_{\mathrm{m}}\right)$ indicative of high-density polyethylene (HDPE) with minimal defects and branching; $130{ }^{\circ} \mathrm{C}$ in the presence of $0.86 \% \mathrm{H}_{2}$. Density measurements further confirmed the production of HDPE $\left(0.98 \mathrm{~g} \mathrm{~cm}^{-3}\right)$.

High-throughput ethylene/ $\mathbf{H}_{2} / 1$-hexene copolymerization Due to a phenomenon known as the comonomer effect, metallocene catalysts can experience an increase in ethylene polymerization activity on the introduction of long-chain $\alpha$-olefins, such as 1 -hexene. ${ }^{3,55-57}$ The origin of this effect is unclear; however, it is most widely accepted that $\alpha$-olefin incorporation decreases polymer crystallinity, which leads to an increase in polymer solubility in the reaction medium. This causes the catalytic sites to become more accessible and allows for more facile monomer diffusion. ${ }^{58-60}$ Additionally, molecular simulations also show that ethylene solubility is enhanced by up to $10 \%$ on the addition of $5 \mathrm{~mol} \%$-hexene at $70-100{ }^{\circ} \mathrm{C}$, which could then lead to an increase in activity. ${ }^{61}$ However, the comonomer effect cannot always be explained as a purely physical phenomenon, and changes in the chemistry of the active sites must be considered. ${ }^{62}$ One possible explanation is a 'trigger mechanism' whereby the active sites of the catalyst coordinate two monomers (in addition to the polymer chain), ${ }^{63}$ with coordination of the second monomer 'triggering' insertion of the first. ${ }^{64}$ This has been expanded to propose that when two different monomers are present (e.g. ethylene and a more electron-rich $\alpha$-olefin) then the $\alpha$-olefin stabilizes the active site and 'triggers' insertion of ethylene, leading to an enhancement in activity. ${ }^{62,65}$

For these catalyst systems, it was postulated that combining the increase in ethylene uptake rate usually observed for ethylene/1-hexene copolymerizations may reduce some of the deactivating effects of $\mathrm{H}_{2}$. The incorporation of longer chain $\alpha$-olefin monomers into polyethylene chains can also increase the 
degree of polymer branching, and therefore lower the melting point, crystallinity, and density. ${ }^{66}$ This increases the flexibility of the polymer and allows applications in packaging, foams, elastic fibers, and adhesives. ${ }^{67}$

Slurry-phase ethylene/ $\mathrm{H}_{2} / 1$-hexene copolymerization high-throughput studies were conducted at $80{ }^{\circ} \mathrm{C}$ for 1 hour or until 5.5 bar ethylene uptake was reached. Polymerizations were run using $5 \mathrm{~mL}$ heptane, $10 \mu \mathrm{mol}$ TiBA scavenger, $0.05-0.10 \mathrm{mg}$ pre-catalyst, 150 or $250 \mu \mathrm{L}$ 1-hexene $(2.5$ or $5.0 \%$ of the total reaction volume), $\left[\mathrm{Al}_{\mathrm{sMAO}}\right]_{0} /[\mathrm{Zr}]_{0}$ of $200,8.3$ bar ethylene, and $0.8 \%$ (0.07 bar) $\mathrm{H}_{2}$ supplied by a mixed $\mathrm{H}_{2} / \mathrm{N}_{2} \quad$ feed. $\quad$ sMAO supported $\quad{ }^{\mathrm{Me}_{2}} \mathrm{SB}\left(\mathrm{Cp}^{\mathrm{Me}}, \mathrm{I}^{*}\right) \mathrm{ZrBr}_{2} \quad\left(\mathbf{4}_{\text {sMAO }}\right), \quad{ }^{\mathrm{Me}}{ }_{2} \mathrm{SB}\left(\mathrm{Cp}^{n \mathrm{Bu}}, \mathrm{I}^{*}\right) \mathrm{ZrCl}_{2} \quad\left(\mathbf{5}_{\text {sMAO }}\right)$, ${ }^{\mathrm{Me}_{2}} \mathrm{SB}\left(\mathrm{Cp}^{\mathrm{Me}}, \mathrm{I}^{*}\right) \mathrm{Zr}\left(\mathrm{CH}_{2} \mathrm{Ph}\right)_{2}\left(\mathbf{7}_{\text {sMAO }}\right)$, and ${ }^{\mathrm{Me}_{2}} \mathrm{SB}\left(\mathrm{Cp}^{\mathrm{Me}}, \mathrm{I}^{*}\right) \mathrm{ZrMe}_{2}\left(\boldsymbol{9}_{\text {sMAO }}\right)$ were studied.

The uptake rate profiles show an initial increase in ethylene uptake rate due to the comonomer effect, which begins to decrease after approximately 300 seconds (Figures S22 and S23). The catalysts experienced an increase in polymerization activity with $125 \mu \mathrm{L}$ 1-hexene and $0.8 \% \mathrm{H}_{2}$ when compared to ethylene/ $\mathrm{H}_{2}$ homopolymerization due to the comonomer effect (Table 3 and S26). However, with $250 \mu \mathrm{L}$ 1-hexene, all catalysts except $\mathbf{7}_{\text {sMaO }}$ experienced a decrease in polymerization activity compared to the ethylene/ $\mathrm{H}_{2}$ system with $125 \mu \mathrm{L}$ 1-hexene. This decrease in activity could be due to competitive coordination between ethylene and 1-hexene monomers at the active metal center; upon coordination, if the rate of 1-hexene insertion is slower than ethylene insertion, the rate of ethylene uptake decreases and leads to a decrease in polymerization activity. ${ }^{68}$ The decrease in activity may also be due to slower rates of monomer insertion; insertion into the branched alkyl active species [R-1-hexene-cat] that forms following 1-hexene insertion is typically slower than insertion into unbranched alkyl active species [R-ethylene-cat] due to the increased steric bulk of the $\alpha$-olefin. ${ }^{69}$ 
Table 3. Slurry-phase ethylene/ $\mathrm{H}_{2} / 1$-hexene copolymerization using sMAO supported complexes in a high-throughput system. ${ }^{a}$

\begin{tabular}{|c|c|c|c|c|}
\hline Catalyst & 1-Hexene ${ }^{b}$ & Activity $^{c}$ & $M_{\mathrm{n}}{ }^{\mathrm{d}}$ & $M_{\mathrm{w}} / M_{\mathrm{n}}$ \\
\hline \multirow{3}{*}{$\mathbf{4}_{\text {SMAO }}$} & 0 & 3500 & 8.9 & 3.4 \\
\hline & 125 & 7900 & 11 & 2.8 \\
\hline & 250 & 4500 & 14 & 2.7 \\
\hline \multirow{3}{*}{$5_{\text {SMAO }}$} & 0 & 4100 & 6.7 & 3.6 \\
\hline & 125 & 21000 & 10 & 2.5 \\
\hline & 250 & 14000 & 12 & 2.4 \\
\hline \multirow{3}{*}{$7_{\text {sMAO }}$} & 0 & 5000 & 7.5 & 3.7 \\
\hline & 125 & 19000 & 8.0 & 3.0 \\
\hline & 250 & 24000 & 11 & 2.8 \\
\hline \multirow{3}{*}{$\mathbf{9}_{\text {SMAO }}$} & 0 & 3400 & 6.9 & 3.6 \\
\hline & 125 & 13000 & 9.2 & 2.8 \\
\hline & 250 & 13000 & 11 & 2.8 \\
\hline
\end{tabular}

(a) Polymerization conditions: $0.8 \% \mathrm{H}_{2},\left[\mathrm{Al}_{\mathrm{sMAO}}\right]_{0} /[\mathrm{Zr}]_{0}=200$, TiBA $(10 \mu \mathrm{mol})$, ethylene $(8.3$ bar $)$, pre-catalyst $(0.05-0.10 \mathrm{mg})$, heptane $(5 \mathrm{~mL})$, and $80{ }^{\circ} \mathrm{C}$; reactions quenched at 5.5 or 8.3 bar ethylene uptake for co- and homopolymerization respectively or after 1 hour; (b) $\mu \mathrm{L}$; (c) $\mathrm{kg}_{\mathrm{PE}} \mathrm{mol}_{\mathrm{Zr}}{ }^{-1} \mathrm{~h}^{-1} \mathrm{bar}^{-1}$, reported to 2 significant figures; (d) $\mathrm{kg} \mathrm{mol}^{-1}$.

A decrease in activity for ethylene/1-hexene copolymerization has been observed in other zirconocene systems, such as for the solution-phase copolymerization of ethylene and 1-hexene using ( $\left.{ }^{2-P h} \mathrm{Ind}\right)_{2} \mathrm{ZrCl}_{2}$ with MAO co-catalyst where activity decreased from 2200 to $960 \mathrm{~kg}_{\mathrm{PE}} \mathrm{mol}_{\mathrm{Zr}}{ }^{-1} \mathrm{~h}^{-1} \mathrm{bar}^{-1}$ with 0 and $0.16 \mathrm{M}$ 1-hexene respectively and 1 bar ethylene. ${ }^{70}$ The deactivating effects of 1 -hexene have also been observed in heterogeneous systems; the copolymerization of ethylene and 1-hexene using $\left({ }^{2,4-\mathrm{Me}} \mathrm{Ind}\right)_{2} \mathrm{ZrCl}_{2}$ supported on silica with MAO co-catalyst showed a decrease in activity from 4640 to $200 \mathrm{~kg}_{\mathrm{PE}} \mathrm{mol}_{\mathrm{Zr}}^{-1} \mathrm{~h}^{-1}$ bar $^{-1}$ with 0 and $0.8 \mathrm{M}$ 1-hexene respectively and 1 bar ethylene. $^{71}$ 
Molecular weights $\left(M_{\mathrm{n}}\right)$ were observed to increase slightly when 1-hexene was added to the system, suggesting that competitive monomer coordination between ethylene, $\mathrm{H}_{2}$ and 1-hexene hindered termination processes; $M_{\mathrm{n}}$ of $6.9,9.2$ and $11 \mathrm{~kg}$ mol-1 for $\mathbf{9}_{\text {sMaO }}$ with $0.8 \% \mathrm{H}_{2}$ and 0,125 and $250 \mu \mathrm{L}$ 1-hexene respectively (Table 3; Figures S27-S29). This may be because the increase in chain propagation from the higher ethylene/1-hexene copolymerization activity is greater than the increase in chain termination caused by chain transfer to $\mathrm{H}_{2}$. An increase in polymer molecular weights for ethylene/1-hexene copolymerization has been observed in solution-phase polymerization using 2,4-cyclopentadien-1-ylidene(isopropylidene)fluoren-9-ylidene zirconium dichloride $\left({ }^{\mathrm{Me}_{2}} \mathrm{CB}(\mathrm{Flu}, \mathrm{Cp}) \mathrm{ZrCl}_{2}\right)$ with $\mathrm{MAO}$ co-catalyst. ${ }^{72}$

The percentage incorporation of 1-hexene in the polymer chain was determined by ${ }^{13} \mathrm{C}\left\{{ }^{1} \mathrm{H}\right\} \mathrm{NMR}$ spectroscopy as $0.6-0.7$ and $1.0-1.1 \mathrm{~mol} \%$ for all catalysts with 125 and $250 \mu \mathrm{L}$ 1-hexene respectively in the presence of $0.8 \% \mathrm{H}_{2}$ (Table $\mathrm{S} 2$ ). CEF showed that Tel,max. decreased as the proportion of 1-hexene in the polymer increased; $T_{\mathrm{el}, \max }=110.5,105.7$, and $103.2{ }^{\circ} \mathrm{C}$ for $\mathbf{5}_{\text {sMAO }}$ with $0.8 \% \mathrm{H}_{2}$ and 0,125 , and $250 \mu \mathrm{L}$ 1-hexene respectively (Table S2; Figures S32 and S33). $T_{\text {el,max. likely decreased as melting temperature and }}$ crystallinity decreased due to the increase in chain branching caused by 1-hexene incorporation weakening the intramolecular interactions between polymer chains. ${ }^{58,73}$

Large scale ethylene/ $\mathrm{H}_{2} / \mathbf{1}$-hexene polymerization sMAO supported ${ }^{\mathrm{Me}} 2 \mathrm{SB}\left(\mathrm{Cp}^{\mathrm{Me}}, \mathrm{I}^{*}\right) \mathrm{ZrCl}_{2}$ $\left(\mathbf{3}_{\text {sMAO }}\right),{ }^{\mathrm{Me}_{2}} \mathrm{SB}\left(\mathrm{Cp}, \mathrm{I}^{*}\right) \mathrm{Zr}\left(\mathrm{CH}_{2} \mathrm{Ph}\right)_{2}\left(\mathbf{6}_{\mathbf{s M A O}}\right),{ }^{\mathrm{Me}_{2}} \mathrm{SB}\left(\mathrm{Cp}^{\mathrm{Me}}, \mathrm{I}^{*}\right) \mathrm{Zr}\left(\mathrm{CH}_{2} \mathrm{Ph}\right)_{2} \quad\left(\mathbf{7}_{\mathrm{sMAO}_{\mathrm{O}}}\right)$, and ${ }^{\mathrm{Me}_{2}} \mathrm{SB}\left(\mathrm{Cp}, \mathrm{I}^{*}\right) \mathrm{ZrMe}_{2}$ $\left(\mathbf{8}_{\text {sMAO}}\right)$ were studied for ethylene/ $\mathrm{H}_{2} / 1$-hexene copolymerization in $2 \mathrm{~L}$ steel reactors with $1 \mathrm{~L}$ hexane, $0.5 \mathrm{mmol}$ TEA, $0.025-0.050 \mathrm{~g}$ pre-catalyst, $\left[\mathrm{Al}_{\mathrm{sMAO}}\right]_{0} /[\mathrm{Zr}]_{0}=200$, and 8 bar ethylene at $80{ }^{\circ} \mathrm{C}$ for 1 hour with $0.86 \%$ ( 0.07 bar) $\mathrm{H}_{2}$ and $10 \mathrm{~mL}$ 1-hexene ( $1 \%$ of the total reaction volume). On the addition of 1-hexene to the ethylene $/ \mathrm{H}_{2}$ system, all catalysts except $\mathbf{7}_{\text {sMaO }}$ experienced an initial increase in ethylene uptake rate and an increase in polymerization activity due to the comonomer effect; activities of 8900 and $12000 \mathrm{~kg}_{\mathrm{PE}}$ molzr $^{-1} \mathrm{~h}^{-1}$ bar $^{-1}$ for $\mathbf{8}_{\text {SMAO }}$ with 0 and $10 \mathrm{~mL}$ 1-hexene respectively (Table 4; Figures S24 and S25). This is similar to the positive comonomer effect observed for solution-phase ethylene/1-hexene copolymerization using $\mathrm{rac}$ - $\mathrm{EBIZrCl}_{2}$ where activity increased by $30 \%$ from 12800 to

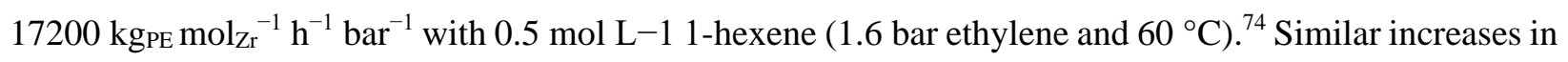


activity on the addition of 1- hexene have also been observed for some Ziegler-Natta-type and Phillips-type polymerization catalysts: $\mathrm{TiCl}_{4} / \mathrm{MgCl}_{2}$ and $\mathrm{TiCl}_{4} / \mathrm{AlCl}_{3} / \mathrm{MgCl}_{2}$ catalysts experienced activities 2.2 and 2.7 times greater respectively on the addition of $0.2 \mathrm{~mol} \mathrm{~L}^{-1}$ 1-hexene ( 1 bar ethylene and 0.2 bar $\mathrm{H}_{2}$ at $\left.60{ }^{\circ} \mathrm{C}\right),{ }^{75}$ and $\mathrm{Cr}(\mathrm{VI}) /$ silica-titania and $\mathrm{Cr}(\mathrm{II}) /$ silica-titania catalysts experienced activities 1.2 and 2.5 times greater respectively on the addition of $0.014 \mathrm{~mol} \mathrm{~L}^{-1} 1$-hexene (38 bar ethylene at 103 and $97{ }^{\circ} \mathrm{C}$ respectively). ${ }^{62}$

Addition of 1-hexene to the ethylene $/ \mathrm{H}_{2}$ system appeared to have no effect on the polymer molecular weights $\left(M_{\mathrm{n}}\right.$ of approximately $5 \mathrm{~kg} \mathrm{~mol}^{-1}$ for all solid catalysts with 0 and $10 \mathrm{~mL} 1$-hexene), leading PE-wax formation (Table 4; Figures S30 and S31). $M_{\mathrm{w}} / M_{\mathrm{n}}$ was relatively narrow for ethylene $/ \mathrm{H}_{2} / 1$-hexene copolymerization $\left(M_{\mathrm{w}} / M_{\mathrm{n}}<4.1\right)$, indicating controlled polymerization (Table 4).

Table 4. Slurry-phase ethylene/ $\mathrm{H}_{2} / 1$-hexene copolymerization using sMAO supported complexes in a $2 \mathrm{~L}$ batch reactor. ${ }^{\mathrm{a}}$

\begin{tabular}{|c|c|c|c|c|}
\hline Catalyst & 1-Hexene $^{\mathbf{b}}$ & Activity $^{\mathbf{c}}$ & $\boldsymbol{M}_{\mathbf{n}}{ }^{\mathbf{d}}$ & $\boldsymbol{M}_{\mathbf{w}} / \boldsymbol{M}_{\mathbf{n}}$ \\
\hline \multirow{2}{*}{$\mathbf{3}_{\text {SMAO }}$} & 0 & 7600 & 5.0 & 3.8 \\
\cline { 2 - 5 } & 10 & 12000 & 4.9 & 3.2 \\
\hline \multirow{2}{*}{ 6 $_{\text {sMAO }}$} & 0 & 6700 & 5.2 & 2.7 \\
\cline { 2 - 5 } & 10 & 11000 & 4.6 & 2.8 \\
\hline \multirow{2}{*}{ 7 $_{\text {sMAO }}$} & 0 & 7200 & 4.6 & 4.1 \\
\cline { 2 - 5 } & 10 & 2600 & 5.3 & 3.7 \\
\hline \multirow{2}{*}{$\mathbf{8}_{\text {sMAO }}$} & 0 & 8900 & 4.8 & 3.2 \\
\cline { 2 - 5 } & 10 & 12000 & 4.5 & 2.8 \\
\hline
\end{tabular}

(a) Polymerization conditions: $0.86 \% \mathrm{H}_{2},\left[\mathrm{Al}_{\mathrm{sMAO}}\right]_{0} /[\mathrm{Zr}]_{0}=200$, TEA $(0.5 \mathrm{mmol})$, ethylene ( 8 bar $)$, pre-catalyst (0.025-0.050 g), hexane (1 L), $80{ }^{\circ} \mathrm{C}$, and 1 hour; (b) $\mathrm{mL}$; (c) $\mathrm{kg}_{\mathrm{PE}} \mathrm{mol}_{\mathrm{Zr}}{ }^{-1} \mathrm{~h}^{-1} \mathrm{bar}^{-1}$, reported to 2 significant figures; (d) $\mathrm{kg} \mathrm{mol}^{-1}$, reported to 2 significant figures.

Solid catalysts $7_{\text {sMAO }}$ and $\mathbf{8}_{\text {sMAO }}$ produced polymers with 0.3 and $0.2 \mathrm{~mol} \%$ 1-hexene incorporation respectively. The polymers produced using $\mathbf{7}_{\text {sMAO }}$ and $\mathbf{8}_{\text {sMAO }}$ showed a $7 \%$ decrease in polymer crystallinity 
(76 and $80 \%$ respectively) and a $1{ }^{\circ} \mathrm{C}$ decrease in $T_{\mathrm{m}}\left(129{ }^{\circ} \mathrm{C}\right.$ for both catalysts) compared to ethylene/ $\mathrm{H}_{2}$ homopolymerization, likely due to an increased amount of chain branching. CEF showed that $T_{\mathrm{el}, \mathrm{max}}$ of the copolymers produced using $\mathbf{7}_{\text {SMAO }}$ and $\mathbf{8}_{\text {SMAO }}$ were similar; 98.4 and $98.7{ }^{\circ} \mathrm{C}$ respectively (Figure S34).

As postulated, the density of the polymers produced using $7_{\text {sMaO }}$ for ethylene $/ \mathrm{H}_{2} / 1$-hexene copolymerization decreased by $3 \%$ compared to ethylene/ $\mathrm{H}_{2}$ polymerization (density of 0.95 and $0.98 \mathrm{~g} \mathrm{~cm}^{-3}$ respectively), likely due to increases in chain branching.

\section{CONCLUSIONS}

Nine solid polymethylaluminoxane supported permethylindenyl zirconocenes ( $\left.\mathrm{sMAO}-{ }^{\mathrm{Me}_{2}} \mathrm{SB}\left(\mathrm{Cp}^{\mathrm{R}}, \mathrm{I}^{*}\right) \mathrm{ZrX} \mathrm{X}_{2}\right)$ have been studied for their capacity to produce polyethylene waxes. Their $\mathrm{H}_{2}$ response in two ethylene polymerization systems was investigated using high-throughput screening and $2 \mathrm{~L}$ batch reactors.

The catalysts showed remarkable resistance to $\mathrm{H}_{2}$ deactivation with an approximately constant ethylene uptake maintained throughout the polymerization runs (up to one hour). In high-throughput conditions, the presence of $\mathrm{H}_{2}$ resulted in a significant decrease in polymer molecular weights; $M_{\mathrm{n}}$ of 120 and $6.1 \mathrm{~kg} \mathrm{~mol}^{-1}$ for sMAO- ${ }^{\mathrm{Me}_{2}} \mathrm{SB}\left(\mathrm{Cp}, \mathrm{I}^{*}\right) \mathrm{ZrMe}_{2}$ with 0 and $1.6 \% \mathrm{H}_{2}$ respectively.

The lowest molecular weights were obtained using sMAO- ${ }^{{ }^{2}}{ }_{2} \mathrm{SB}\left(\mathrm{Cp}, \mathrm{I}^{*}\right) \mathrm{ZrCl}_{2}$ in the $2 \mathrm{~L}$ batch reactor with $3.50 \% \mathrm{H}_{2}\left(M_{\mathrm{n}}\right.$ of $\left.1.7 \mathrm{~kg} \mathrm{~mol}^{-1}\right)$, highlighting the applications of these catalysts for the production of commercially viable polyethylene waxes. The HDPE produced had very uniform 'popcorn' morphologies, narrow molecular weight distributions, and high crystallinities.

The addition of 1-hexene to the ethylene/ $\mathrm{H}_{2}$ system initially lead to an increase in ethylene uptake

rate and polymerization activity (from 3400 to $13000 \mathrm{~kg}_{\mathrm{PE}} \mathrm{mol}_{\mathrm{Zr}}{ }^{-1} \mathrm{~h}^{-1} \mathrm{bar}^{-1}$ for sMAO- ${ }^{\mathrm{Me}_{2}} \mathrm{SB}\left(\mathrm{Cp}^{\mathrm{Me}}, \mathrm{I}^{*}\right) \mathrm{ZrMe}_{2}$ with 0 and $125 \mu \mathrm{L}$ 1-hexene in the high-throughput system). In the batch reactor, the addition of 1-hexene led to no change in polymer molecular weights $\left(M_{\mathrm{n}}\right.$ of $5 \mathrm{~kg} \mathrm{~mol}^{-1}$ for all catalysts with 0 and $10 \mathrm{~mL}$ 1-hexene respectively) and produced polymers with low 1-hexene incorporation $(<0.3 \mathrm{~mol} \%)$. 
The key challenge when using metallocene polymerization catalysts to produce PE-waxes is to balance the desired decrease in polymer molecular weights observed in the presence of $\mathrm{H}_{2}$ with the undesired reduction in polymerization activity that can also occur. Although these catalysts experienced a decrease in polymerization activity when $\mathrm{H}_{2}$ was introduced to the system, the very low molecular weights of the polymers produced, coupled with the high stability of the catalysts the presence of $\mathrm{H}_{2}$, makes them ideal candidates to produce polyethylene metallocene waxes on an industrial scale. In addition, the decrease in density in the presence of 1-hexene, coupled with the formation of PE-waxes, offers the possibility of a wide range of applications.

\section{EXPERIMENTAL}

High-throughput screening Polymerization experiments were conducted by Dr. Alessio Mingione at HTExplore (University of Naples, Italy) in a Freeslate Parallel Pressure Reactor (PPR) platform consisting of 48 reaction cells contained within a triple MBraun LabMaster Glovebox. The cells (geometric volume $\sim 23 \mathrm{~mL}$, working volume $5 \mathrm{~mL}$ ) were individually controlled with monitoring of temperature and pressure. Slurry-phase polymerizations were run in semi-continuous mode. Two Vortex stir plates fitted with $6 \times 8$ racks held the catalyst system components (pre-catalyst and scavenger). The injection system consisted of a dual-arm robot with specialized needles and injectors. Liquid solvents, diluents, and monomers were fed through syringe pumps, with gaseous monomers and diluents fed through direct lines with solenoid valves to individual cells. 34 Heptane solvent $(5 \mathrm{~mL})$ and TiBA scavenger $(10 \mu \mathrm{mmol})$ were added to the PPR via robotic syringes, which were then heated to $80^{\circ} \mathrm{C}$ and pressurized to 8.3 bar with ethylene. When required, $\mathrm{H}_{2}$ was added to the reaction vessel via a 0.8 or $1.6 \%$ mixed $\mathrm{H}_{2} / \mathrm{N}_{2}$ feed. Pre-catalyst $(0.05-0.15 \mathrm{mg}$ in heptane slurry) and 1-hexene (when required) were injected with robotic syringes and chased by a certain amount of heptane solvent. The reactions were run for 1 hour or until a certain ethylene uptake was reached ( 8.3 bar for ethylene homopolymerization and 5.5 bar for ethylene/ $\mathrm{H}_{2} / 1$-hexene copolymerization), following which the reaction was quenched with an excess of dry air. The polymer samples were transferred to a Genevac EZ-Plus centrifugal evaporator to remove volatiles and then dried under vacuum overnight. 
Large scale batch polymerization Polymerizations were performed by Mr. Thawesak Parawan, Mr. Somjet Songnoey, or Mr. Pongsiri Kaeoyok at SCG Chemicals Co., Ltd. (Rayong, Thailand). A 2.5 L steel reactor was charged with hexane $(850 \mathrm{~mL})$ and TEA scavenger $\left(0.5 \mathrm{mmol} \mathrm{L}^{-1}\right)$ and saturated with ethylene gas (2 bar). 1-hexene, when required, was added at an overpressure. The reactor was heated to temperature and a mixture of pre-catalyst $(0.025-0.050 \mathrm{~g})$ in hexane $(20 \mathrm{~mL})$ was added and washed in with a further $130 \mathrm{~mL}$ hexane. The ethylene pressure was set to 8 bar and the polymerizations run for 1 hour. On completion, the polymer was decanted and dried in an oven overnight.

\section{ASSOCIATED CONTENT}

Supporting Information. The Supporting Information contains general experimental details and additional polymerization data as described by Figures S1-S34 and Tables S1-S2 in the text. This material is available free of charge via the Internet at http://pubs.acs.org.

\section{AUTHOR INFORMATION}

Corresponding Author

*E mail: dermot.ohare@chem.ox.ac.uk

Notes

The authors declare no competing financial interest.

\section{ACKNOWLEDGMENT}

J. V. L., J.-C. B. and Z. R. T. (SCG Research Fellowship) would like to thank SCG Chemicals Co., Ltd. (Thailand) for financial support; Prof. Vincenzo Busico for the use of HTExplore (University of Naples), Prof. Roberta Cipullo and Dr. Alessio Mingione for running the high-throughput polymerization experiments and polymer analyses (HTExplore); SCG Chemicals Co., Ltd. (Rayong, Thailand) for use of the $2 \mathrm{~L}$ batch reactors and Mr. Thawesak Parawan, Mr. Somjet Songnoey, and Mr. Pongsiri Kaeoyok (SCG Chemicals Co., Ltd.) for running batch polymerization experiments and polymer analyses. 


\section{REFERENCES}

1. Klosin, J.; Fontaine, P. P.; Figueroa, R., Development of group IV molecular catalysts for high temperature ethylene- $\alpha$-olefin copolymerization reactions. Acc. Chem. Res. 2015, 48 (7), 2004-2016.

2. Hamielec, A. E.; Soares, J. B. P., Polymerization reaction engineering - metallocene catalysts. Prog. Polym. Sci. 1996, 21 (4), 651-706.

3. Kaminsky, W., Zirconocene catalysts for olefin polymerization. Catal. Today 1994, 20 (2), 257-271.

4. Soares, J. B. P.; Hamielec, A. E., Effect of hydrogen and of catalyst prepolymerization with propylene on the polymerization kinetics of ethylene with a non-supported heterogeneous Ziegler-Natta catalyst. Polymer 1996, 37 (20), 4599-4605.

5. Kaminsky, W.; Lüker, H., Influence of hydrogen on the polymerization of ethylene with the homogeneous ziegler system bis(cyclopentadienyl)zirconiumdichloride/aluminoxane. Makromol. Chem. Rapid. Comm. 1984, 5 (4), 225-228.

6. Bohm, L. L., The ethylene polymerization with Ziegler catalysts: fifty years after the discovery. Angew. Chem., Int. Ed. 2003, 42 (41), 5010-5030.

7. Resconi, L.; Cavallo, L.; Fait, A.; Piemontesi, F., Selectivity in propene polymerization with metallocene catalysts. Chem. Rev. 2000, 100 (4), 1253-1346.

8. Hlatky, G. G., Heterogeneous single-site catalysts for olefin polymerization. Chem. Rev. 2000, 100 (4), 1347-1376.

9. Kaminsky, W.; Funck, A.; Haehnsen, H., New application for metallocene catalysts in olefin polymerization. Dalton Trans. 2009, (41), 8803-8810.

10. Sedov, I.; Makhaev, V.; Matkovskii, P. E., Single-site catalysts in the industrial production of polyethylene. Catal. Ind. 2012, 4, 129-140.

11. Lamb, J. V.; Buffet, J.-C.; Turner, Z. R.; O'Hare, D., Group 4 permethylindenyl complexes for slurry-phase polymerisation of ethylene. Polym. Chem. 2019, 10 (11), 1386-1398.

12. Lamb, J. V.; Buffet, J.-C.; Matley, J. E.; Wright, C. M. R.; Turner, Z. R.; O'Hare, D., Group 4 permethylindenyl complexes for the polymerisation of L-, D- and rac-lactide monomers. Dalton Trans. 2019, 48 (7), 2510-2520.

13. Lamb, J.; O’Hare, D.; Buffet, J.-C.; Khamnaen, T.; Charernsuk, M.; Parawan, T.; Charoenchaidet, S. Unsymmetrical metallocene catalysts and uses thereof. WO2017194943A1, 2017.

14. Lamb, J. V.; Abell, J. C.; McLaren, J. E.; Buffet, J.-C.; Turner, Z. R.; O'Hare, D., Slurry-phase ethylene polymerisation using group 4 ansa-bridged permethylindenyl complexes supported on polymethylaluminoxane. Mol. Catal. 2020, 484, 110735.

15. Lamb, J. V.; Buffet, J.-C.; Turner, Z. R.; O’Hare, D., Ethylene polymerization using zirconocenes supported on pentafluorophenyl-modified solid polymethylaluminoxane.

Macromolecules 2020, 53 (3), 929-935.

16. Finlayson, M. F.; Garrison, C. C.; Guerra, R. E.; Guest, M. J.; Kolthammer, B. W. S.; Parikh, D. R.; Ueligger, S. M. Ultra-low molecular weight ethylene polymers WO1997026287A1, 1997.

17. Napoli, M.; De Vita, R.; Immediata, I.; Longo, P.; Guerra, G., Polyethylene waxes by metallocenes. Polym. Adv. Technol. 2011, 22 (4), 458-462. 
18. Umare, P. S.; Tiwari, A. J.; Antony, R.; Tembe, G. L.; Trivedi, B., Synthesis of ultralow-molecular-weight polyethylene wax using a bulky Ti(IV) aryloxide-alkyl aluminum catalytic system. Appl. Organomet. Chem. 2007, 21 (8), 652-660.

19. Krendlinger, E.; Nowicki, H.-D. Use of metallocene waxes in powder paints. US20050176866A1, 2005.

20. El-Nahas, H. H.; Gad, Y. H.; El-Hady, M. A.; Ramadan, A. B., The study of compatibility of polyethylene and polypropylene by using irradiated polyethylene wax. Radiat. Eff. Defects Solids 2012, 167 (5), 367-376.

21. Ciesińska, W.; Liszyńska, B.; Zieliński, J., Selected thermal properties of polyethylene waxes. J. Therm. Anal. Calorim. 2016, 125 (3), 1439-1443.

22. Herrmann, H.-F.; Hohner, G. Method of using polyolefin waxes. US6080902A, 2000.

23. Eguchi, A.; Sakai, H.; Kigami, T.; Suzuki, C.; Aoki, T. Toner for developing electrostatic latent images US5928825, 1999.

24. Leotsakos, G.; Gravatt, W. M.; Smith, C. P.; Kocur, M. A. Wax dispersion formulations, method of producing same, and uses US8853284B2, 2014.

25. Wahle, B.; Waltenberger, P.; Klink, C.; Thomas, F.; Engels, T. Process for the production of storage stable wax dispersions. US5723137A, 1998.

26. Leotsakos, G.; Gravatt, W. M.; Smith, C. P.; A. Kocur, M. Novel wax dispersion formulations, method of producing same, and uses 2283094B1, 2012.

27. Billuart, G.; Bourgeat-Lami, E.; Lansalot, M.; Monteil, V., Free radical emulsion polymerization of ethylene. Macromolecules 2014, 47 (19), 6591-6600.

28. Xu, X.; Zheng, A. N.; Zhou, X. D.; Guan, Y.; Pan, Y. F.; Xiao, H. N., Antimicrobial polyethylene wax emulsion and its application on active paper-based packaging material. $J$. Appl. Polym. Sci. 2015, 132 (27), 42214.

29. Luker, H. Polyethylene wax, and a process for the preparation thereof US5023388A, 1991.

30. Chang, M. Method for preparing polyethylene wax by gas phase polymerization. US4914253A, 1990.

31. Broach, J. R.; Thorner, J., High-throughput screening for drug discovery. Nature 1996, 384 (6604), 14-16.

32. Boussie, T. R.; Diamond, G. M.; Goh, C.; Hall, K. A.; LaPointe, A. M.; Leclerc, M.; Lund, C.; Murphy, V.; Shoemaker, J. A. W.; Tracht, U.; Turner, H.; Zhang, J.; Uno, T.; Rosen, R. K.; Stevens, J. C., A fully integrated high-throughput screening methodology for the discovery of new polyolefin catalysts: Discovery of a new class of high temperature single-site group (IV) copolymerization catalysts. J. Am. Chem. Soc. 2003, 125 (14), 4306-4317.

33. Busico, V.; Pellecchia, R.; Cutillo, F.; Cipullo, R., High-throughput screening in olefinpolymerization catalysis: from serendipitous discovery towards rational understanding.

Macromol. Rapid Commun. 2009, 30 (20), 1697-1708.

34. Busico, V.; Cipullo, R.; Mingione, A.; Rongo, L., Accelerating the research approach to Ziegler-Natta catalysts. Ind. Eng. Chem. Res. 2016, 55 (10), 2686-2695.

35. Meier, M. A. R.; Hoogenboom, R.; Schubert, U. S., Combinatorial methods, automated synthesis and high-throughput screening in polymer research: The evolution continues. Macromol. Rapid Commun. 2004, 25 (1), 21-33.

36. Boussie, T. R.; Diamond, G. M.; Goh, C.; Hall, K. A.; LaPointe, A. M.; Leclerc, M. K.; Murphy, V.; Shoemaker, J. A. W.; Turner, H.; Rosen, R. K.; Stevens, J. C.; Alfano, F.; Busico, V.; Cipullo, R.; Talarico, G., Nonconventional catalysts for isotactic propene 
polymerization in solution developed by using high-throughput-screening technologies. Angew. Chem., Int. Ed. 2006, 45 (20), 3278-3283.

37. Jones, D. J.; Gibson, V. C.; Green, S. M.; Maddox, P. J., Discovery of a new family of chromium ethylene polymerisation catalysts using high throughput screening methodology. Chem. Commun. 2002, (10), 1038-1039.

38. Frazier, K. A.; Boone, H.; Vosepka, P. C.; Stevens, J. C. High activity olefin polymerization catalyst and process. 2005.

39. Thorshaug, K.; Stovneng, J. A.; Rytter, E.; Ystenes, M., Termination, isomerization, and propagation reactions during ethene polymerization catalyzed by $\mathrm{Cp} 2 \mathrm{Zr}-\mathrm{R}+$ and $\mathrm{Cp} * \mathrm{Zr}-2-\mathrm{R}+$.

An experimental and theoretical investigation. Macromolecules 1998, 31 (21), 7149-7165.

40. $\quad$ Rappe, A. T.; Skiff, W. M.; Casewit, C. J., Modeling metal-catalyzed olefin polymerization. Chem. Rev. 2000, 100 (4), 1435-1456.

41. Quintanilla, E.; di Lena, F.; Chen, P., Chain transfer to aluminium in MAO-activated metallocene-catalyzed polymerization reactions. Chem. Commun. 2006, (41), 4309-4311.

42. Posch, W., 3 - Polyolefins. In Applied Plastics Engineering Handbook, Kutz, M., Ed. William Andrew Publishing: Oxford, 2011; pp 23-48.

43. Novstrup, K. A.; Travia, N. E.; Medvedev, G. A.; Stanciu, C.; Switzer, J. M.; Thomson, K. T.; Delgass, W. N.; Abu-Omar, M. M.; Caruthers, J. M., Mechanistic detail revealed via comprehensive kinetic modeling of [rac-C2H4(1-indenyl)2ZrMe2]-catalyzed 1hexene polymerization. J. Am. Chem. Soc. 2010, 132 (2), 558-566.

44. Christianson, M. D.; Tan, E. H. P.; Landis, C. R., Stopped-flow NMR: Determining the kinetics of [rac-(C2H4(1-indenyl)2)ZrMe][MeB(C6F5)3]-catalyzed polymerization of 1-hexene by direct observation. J. Am. Chem. Soc. 2010, 132 (33), 11461-11463.

45. Al-Humydi, A.; Garrison, J. C.; Mohammed, M.; Youngs, W. J.; Collins, S., Propene polymerization using ansa-metallocenium ions: catalyst deactivation processes during monomer consumption and molecular structures of the products formed. Polyhedron 2005, 24 (11), 12341249.

46. Moscato, B. M.; Zhu, B.; Landis, C. R., Mechanistic investigations into the behavior of a labeled zirconocene polymerization catalyst. Organometallics 2012, 31 (5), 2097-2107.

47. Nelsen, D. L.; Anding, B. J.; Sawicki, J. L.; Christianson, M. D.; Arriola, D. J.; Landis, C. R., Chromophore quench-labeling: an approach to quantifying catalyst speciation as demonstrated for (EBI)ZrMe2/B(C6F5)3-catalyzed polymerization of 1-hexene. ACS Catal. 2016, 6 (11), 7398-7408.

48. $\quad$ Song, F. Q.; Cannon, R. D.; Bochmann, M., Zirconocene-catalyzed propene polymerization: a quenched-flow kinetic study. J. Am. Chem. Soc. 2003, 125 (25), 7641-7653.

49. Bochmann, M., The chemistry of catalyst activation: the case of group 4 polymerization catalysts. Organometallics 2010, 29 (21), 4711-4740.

50. Chu, K. J.; Soares, J. B. P.; Penlidis, A., Effect of hydrogen on ethylene polymerization using in-situ supported metallocene catalysts. Macromol. Chem. and Phys. 2000, 201 (5), 552557.

51. Shamiri, A.; Chakrabarti, M. H.; Jahan, S.; Hussain, M. A.; Kaminsky, W.; Aravind, P. V.; Yehye, W. A., The influence of Ziegler-Natta and metallocene catalysts on polyolefin structure, properties, and processing ability. Materials 2014, 7 (7), 5069-5108.

52. Chandrasekhar, V., Inorganic and organometallic polymers. Springer: 2005. 
53. Ramos, J.; Cruz, V.; Munoz-Escalona, A.; Martinez-Salazar, J., Ab initio study of hydrogenolysis as a chain transfer mechanism in olefin polymerization catalyzed by metallocenes. Polymer 2000, 41 (16), 6161-6169.

54. Sivalingam, G.; Natarajan, V.; Sarma, K. R.; Parasuveera, U., Solubility of ethylene in the presence of hydrogen in process solvents under polymerization conditions. Ind. Eng. Chem. Res. 2008, 47 (22), 8940-8946.

55. Kaminsky, W.; Piel, C., Tailoring polyolefins by metallocene catalysis: Kinetic and mechanistic aspects. J. Mol. Catal. A: Chemical 2004, 213 (1), 15-19.

56. Piel, C.; Starck, P.; Seppälä, J. V.; Kaminsky, W., Thermal and mechanical analysis of metallocene-catalyzed ethene- $\alpha$-olefin copolymers: The influence of the length and number of the crystallizing side chains. J. Polym. Sci. A: Polym. Chem. 2006, 44 (5), 1600-1612.

57. Ushakova, T. M.; Starchak, E. E.; Krasheninnikov, V. G.; Samoilenko, A. A.; Ivchenko, P. V.; Nifant'ev, I. E.; Novokshonova, L. A., Ethylene polymerization and ethylene-1hexene copolymerization over immobilized metallocene catalysts. Kinet. Catal. 2012, 53 (1), 75 83.

58. Marques, M. D. F. V.; Tiosso, R. B., Comparison of ethylene/1-hexene copolymerization performance using metallocene catalysts supported on both silica and Brazilian mineral clay. $J$. Mater. Sci. Eng. Adv. Tech. 2011, 4 (2), 149-173.

59. Awudza, J. A. M.; Tait, P. J. T., The "comonomer effect" in ethylene/ $\alpha$-olefin copolymerization using homogeneous and silica-supported $\mathrm{Cp} 2 \mathrm{ZrCl} 2 / \mathrm{MAO}$ catalyst systems: Some insights from the kinetics of polymerization, active center studies, and polymerization temperature. J. Polym. Sci. A: Polym. Chem. 2008, 46 (1), 267-277.

60. Novak, A.; Bobak, M.; Kosek, J.; Banaszak, B. J.; Lo, D.; Widya, T.; Ray, W. H.; de Pablo, J. J., Ethylene and 1-hexene sorption in LLDPE under typical gas-phase reactor conditions: experiments. J. Appl. Polym. Sci. 2006, 100 (2), 1124-1136.

61. Banasazak, B. J.; Lo, D.; Widya, T.; Ray, W. H.; de Pablo, J. J.; Novak, A.; Kosek, J., Ethylene and 1-hexene sorption in LLDPE under typical gas phase reactor conditions: a priori simulation and modeling for prediction of experimental observations. Macromolecules 2004, 37 (24), 9139-9150.

62. McDaniel, M. P.; Schwerdtfeger, E. D.; Jensen, M. D., The "comonomer effect" on chromium polymerization catalysts. J. Catal. 2014, 314, 109-116.

63. Chien, J. C. W.; Yu, Z.; Marques, M. M.; Flores, J. C.; Rausch, M. D., Polymerizations of olefins and diolefins catalyzed by monocyclopentadienyltitanium complexes containing a (dimethylamino)ethyl substituent and comparison with ansa-zirconocene systems. J. Polym. Sci. A: Polym. Chem. 1998, 36 (2), 319-328.

64. Ystenes, M., The trigger mechanism for polymerization of $\alpha$-olefins with Ziegler-Natta catalysts: A new model based on interaction of two monomers at the transition state and monomer activation of the catalytic centers. J. Catal. 1991, 129 (2), 383-401.

65. Yang, Q.; Jensen, M. D.; McDaniel, M. P., Alternative view of long chain branch formation by metallocene catalysts. Macromolecules 2010, 43 (21), 8836-8852.

66. Paredes, B.; van Grieken, R.; Carrero, A.; Suarez, I.; Soares, J. B. P., Ethylene/1hexene copolymers produced with $\mathrm{MAO} /(\mathrm{nBuCp}) 2 \mathrm{ZrCl} 2$ supported on SBA-15 materials with different pore sizes. Macromol. Chem. and Phys. 2011, 212 (15), 1590-1599.

67. Kaminsky, W., New polymers by metallocene catalysis. Macromol. Chem. and Phys. 1996, 197 (12), 3907-3945. 
68. Chien, J. C. W.; Nozaki, T., Ethylene-hexene copolymerization by heterogeneous and homogeneous Ziegler-Natta catalysts and the "comonomer" effect. J. Polym. Sci. A: Polym.

Chem. 1993, 31 (1), 227-237.

69. Fink, G.; Mülhaupt, R.; Brintzinger, H. H., Ziegler Catalysts: Recent Scientific Innovations and Technological Improvements. Springer Berlin Heidelberg: 2012.

70. Jian-ding, Y.; Zhi-qiang, F.; Wei, W., Strong influences of polymerization temperature on ethylene/1-hexene copolymerization catalyzed by (2-PhInd) $2 \mathrm{ZrCl} 2 /$ methyl aluminoxane. $J$. Zhejiang Univ. Sci. B 2005, 6 (10), 1009-1014.

71. Wang, W.; Fan, Z. Q.; Feng, L. X., Ethylene polymerization and ethylene/1-hexene copolymerization using homogeneous and heterogeneous unbridged bisindenyl zirconocene catalysts. Eur. Polym. J. 2005, 41 (10), 2380-2387.

72. Herfert, N.; Montag, P.; Fink, G., Elementary processes of the Ziegler catalysis, 7. Ethylene, $\alpha$-olefin and norbornene copolymerization with the stereorigid catalyst systems iPr[FluCp]ZrCl2/MAO and Me2Si[Ind]2ZrCl2/MAO. Makromol. Chem. 1993, 194 (11), 31673182.

73. Mark, J. E., Polymer Data Handbook. Oxford University Press: 2009.

74. Quijada, R.; Dupont, J.; Miranda, M. S. L.; Scipioni, R. B.; Galland, G. B., Copolymerization of ethylene with 1-hexene and 1-octene: correlation between type of catalyst and comonomer incorporated. Macromol. Chem. and Phys. 1995, 196 (12), 3991-4000.

75. Chen, Y.-p.; Fan, Z.-q., Ethylene/1-hexene copolymerization with TiCl4/MgCl2/AlCl3 catalyst in the presence of hydrogen. Eur. Polym. J. 2006, 42 (10), 2441-2449. 